NBER WORKING PAPER SERIES

\title{
NTERNATIONAL DIFFERENCES IN MALE \\ WAGE INEQUALITY: INSTITUTIONS \\ VERSUS MARKET FORCES
}

Francine D. Blau

Lawrence M. Kahn

Working Paper No. 4678

\author{
NATIONAL BUREAU OF ECONOMIC RESEARCH \\ 1050 Massachusetts Avenue \\ Cambridge, MA 02138 \\ March 1994
}

We are grateful to David Blanchflower, Per-Anders Edin and Andrea Ichino for their help in acquiring data. Portions of this work were completed while the authors were visiting fellows at the Australian National University, Canberra. We have benefitted from the helpful comments of participants at the University of Hlinois and Comell University Labor Economics Workshops. This paper is part of NBER's research program in Labor Studies. Any opizions expressed are those of the authors and not those of the National Bureau of Economic Research. 
NBER Working Paper \#4678

March 1994

\title{
INTERNATIONAL DIFFERENCES IN MALE \\ WAGE INEQUALITY: INSTITUTIONS \\ VERSUS MARKET FORCES
}

\begin{abstract}
While changes in the demand for skilled labor appear to have led to a widening of the wage structures in many countries during the 1980 s, considerable differences in the level of wage inequality remain. In this paper, we examine the sources of these differences, focusing primarily on explaining the considerably higher level of wage inequality in the U.S. We find that the greater overall dispersion of the U.S. wage distribution reflects considerably more compression at the bottom of the distribution in the other countries, but relatively little difference in the degree of wage inequality at the top. While differences in the distribution of measured characteristics help to explain some aspects of the international differences, U.S. labor market prices--that is, higher rewards to labor market skills--are an important factor. Labor market institutions, chiefly the relatively decentralized wage-setting mechanisms in the U.S. compared to other countries, appear to provide the most persuasive explanation for these international differences in prices. In contrast, the pattern of cross-country differences in relative supplies of and demands for skills does not appear to be consistent with the pattern of observed differences in wage inequality.

Francine D. Blau

Institute of Labor \& Industrial Relations University of Illinois 504 E. Armory Avenue Champaign, IL 61820 and NBER

Lawrence M. Kahn Institute of Labor \& Industrial Relations University of Illinois 504 E. Armory Avenue Champaign, IL 61820
\end{abstract}




\section{Introduction}

The level of wage inequality generated by a country's labor market is of fundamental importance for those interested in understanding poverty, social stratification and economic incentives facing workers. Labor eamings are by far the most important component of income for individuals who are employed; hence, in the absence of any compensatory government policies, low living standards in market economies will be associated with low labor incomes. More generally, labor market inequality is a major determinant of disparities in living standards. The level of labor market inequality may also influence the solidarity that individuals feel with one another. Workers with similar eamings most likely feel more in common with each other than those with vastly different economic rewards and status.

To the extent that labor market inequality reflects economic returns to skills (as opposed to heterogeneity in skill levels across individuals), intemational differences in inequality imply differences in economic incentives. Countries with high rewards to skills have a wage structure that encourages skill acquisition by their workers, while the compression of wage premia for skills may dampen workers' incentives to acquire appropriate training. Moreover, centralized wage-setting mechanisms which reduce wage variation tend to limit firms' flexibility in responding to differences in market conditions across industries or geographical areas. 2 Also of concern is that relatively high wages for low skill groups may reduce their relative employment. ${ }^{3}$ On the other hand, a down-side of high rewards to labor

1 An example of the importance of labor market inequality is provided by the U.S. experience in the 1980s when rising wage inequality was sufficient to counteract the effects of economic expansion in reducing poverty (Blank, 1991; Cutler and Katz, 1991).

2 Employers have voiced both these complaints about Sweden's "solidarity" wage policy, and that country's generous student stipends and subsidized loans for higher education may be viewed in part as a means of offsetting the distortions caused by wage compression (Edin and Holmlund, forthcoming).

3 For example, Katz, Loveman and Blanchflower (forthcoming) report that in France, where the minimum wage increased from 45.7 to 53.3 percent of median earnings from 1967 to 1987 , the problem of youth unemployment has been more severe and the duration of unemployment has tended to be longer than in other OECD countries. 
market skills is that they penalize demographic groups with below average levels of skills, even in the absence of explicit discrimination against them. For example, the rising rewards to skills in the U.S. in the 1980s have been found to reduce the relative wages of black workers (Juhn, Murphy and Pierce, 1991) and immigrants (LaLonde and Topel, 1992); and Blau and Kahn (1992 and forthcoming) found that the higher rewards to skills in the U.S. compared to other industrialized countries contributed to a higher gender pay gap in the U.S.

Considerable attention has lately been focused on the trend toward rising wage inequality that has been occurring in most of the industrialized countries. ${ }^{4}$ Evidence that inequality increased in different countries with different institutional structures suggests that similar forces have been at work. For example, it has been suggested that technology and international trade have raised the relative demand for skilled workers among industrialized nations (Katz, Loveman and Blanchflower, forthcoming).

While changes in the demand for skilled labor appear to have led to a widening of the wage structures in many countries during the 1980s, considerable differences in the level of wage inequality remain. Of particular interest to us, the United States has a far greater dispersion of wages than other industrialized countries (Blanchflower and Freeman, 1992; Blau and Kahn, 1992 and forthcoming). Previous international comparative work on wage inequality has focused on recent changes in wage dispersion. In this paper, we are concerned with understanding the fundamental causes of the higher level of wage inequality in the U.S. compared to other industrialized countries in the $1980 \mathrm{~s}$. We concentrate on males in order to focus on a relatively homogeneous sample of workers for each country. 5

4 For evidence of rising inequality in several countries, see Katz, Loveman and Blanchflower (forthcoming), Juhn, Murphy and Pierce (1993), Katz and Murphy (1992), Bound and Johnson (1992), Erickson and Ichino (forthcoming), Edin and Holmlund (forthcoming), Davis (1992), and Gottschalk and Joyce (1991).

5 In Blau and Kahn (1992 and forthcoming), we consider the consequences of differences in wage inequality across countries for international differences in the gender gap. 
The basic pattern of international differences in wage inequality that we seek to explain is illustrated in Figure 1. As expected based on previous work, the U.S. has a considerably higher level of wage inequality than the other industrial countries in our sample. Panels (a) and (b) of Figure 1 indicate that both the standard deviation of log wages and the 90-10 percentile log wage differential are considerably greater in the U.S. than in the other countries. Interestingly, however, this higher level of inequality reflects considerably more compression at the bottom of the distribution in the other countries relative to the U.S., but relatively little difference in the degree of wage inequality at the top of the distribution. Thus, while the 5010 percentile wage differential is much larger in the U.S. than elsewhere (panel c), the U.S. 90-50 differential is quite similar to that in the other countries (panel d). This pattern of greater compression at the bottom is important from a policy perspective in that it implies that the labor market reward structure in other countries generates less poverty and relatively higher incomes for less skilled groups than in the U.S.7 Of course, as suggested above, there are potential costs of wage compression which would have to be compared to these benefits in deciding whether this is a desirable approach.

In the empirical work below, we focus on three possible explanations for these international differences in patterns of wage inequality. We first examine the role of differences across countries in the distribution of measured characteristics. We conclude that while measured characteristics help to explain some aspects of the international differences, U.S. labor market prices-that is, higher rewards to labor market skills and higher rents received for employment in favored sectors-are an important factor contributing to the observed differences in inequality between the U.S. and other countries.

- Details of the data sources and the method of calculating hours-corrected eamings are given below.

7 The claim about poverty holds if we are comparing countries with similar average real wage levels, as is the case here. For example, in 1988, hourly compensation in manufacturing in the OECD countries other than the U.S. averaged $98 \%$ of the U.S. level, adjusting for exchange rates (U. S. Department of Commerce, 1992, p. 841). 
Second, we assess the contribution of labor market institutions to explaining the differences in wage inequality. The United States has a largely nonunion labor market with very decentralized wage-setting even in the union sector. The other countries have considerably higher rates of unionization, and most of them have much more centralized wagesetting processes than those of the U.S. union sector. Further, in several countries, the terms of collective bargaining agreements are routinely extended to cover nonunion workers, and their larger union sectors may induce greater emulation of the union wage structure by the nonunion sector. Finally, in some of the countries, the government or the union movement has followed explicit policies to raise the relative pay of the lowest-paid workers.

Consideration of labor market institutions thus suggests less labor market inequality in these other countries than in the U.S.; and may also imply greater compression at the bottom of the distribution than at the top. This is, of course, consistent with the pattern of inequality which we identify empirically. Moreover, we present information on the nature of union and nonunion patterns of inequality which reveals interesting features of the differences between the U.S. and other countries in the impact of labor market institutions. Specifically, our results imply that union pay policies which bring up the bottom of the union wage distribution are common to all countries, including the U.S. However, unions in other countries appear to be more successful than U.S. unions both in reducing inequality in the union sector and in extending such policies to the nonunion sector.

Third, we examine international differences in the supply of and demand for labor market skills as an alternative explanation for the observed differences in inequality between the U.S. and other countries. We find that market forces, as best as we can measure them, do not appear to be a viable explanation for the international differences, further increasing our confidence that institutions are important. Finally, examining the impact of centralization across the countries in our sample more generally, we find that the degree of wage centralization, as commonly measured by comparative industrial relations researchers, is 
negatively associated with wage dispersion, the 50-10 differential in the log of wages, and the pay gap between middle and low skill workers.

\section{Determinants of Wage Inequality: Skills and Institutions}

Wage inequality as measured by overall wage variation or by the wage gap between workers at different parts of the distribution (e.g. the 10th vs. the 50th percentile) is affected by the distribution of skills, both measured and unmeasured, and the prices determined for those skills in the labor market. This price structure may include rents received by individuals empioyed in certain favored sectors. Prices, in turn, are influenced by both market and institutional forces.

Market forces determine skill prices through the interaction of the supply and demand for skills. Suppose that workers of different skill levels (e.g. high school or college educated workers) are imperfect substitutes in production. Then differences in the relative supply of or demand for skills will produce differences in relative wages across countries. ${ }^{B}$ The effects of demand can be felt both within and between industries. Final demand for output in one country may favor industries that (world-wide) disproportionately employ highly skilled workers, relative to final demand in other countries. If such is the case, then the relative demand for skilled workers in the former country will be higher than in the latter; and, all else equal, we would expect skilled workers to do relatively well even in industries not directly affected by the high demand level. It is also possible that the relative demand for highly skilled labor is greater in each industry in one country than another, if different technologies are employed.

Institutional factors include the extent of collective bargaining coverage, the scope of collective bargaining where it occurs, union pay policies, and govemment policy toward the

B This assumes barriers to the mobility of capital, labor, and/or goods across national boundaries so that skill prices are not equalized.

DNTWAEZ.DOC 2/22/94 3:27 PM 
labor market. From each of these perspectives, we expect the U.S. to have a more unequal wage structure than other countries. The following decomposition of a country's overall level of wage inequality is useful in understanding the role of unions in producing differences in inequality across countries:

$$
v_{i}=\alpha_{i} v_{a i}+\left(1-\alpha_{j}\right) v_{n i}+\alpha_{i}\left(w_{a i}-w_{i j}^{*}\right)^{2}+\left(1-\alpha_{i}\right)\left(w_{n i}-w^{*}{ }^{2}{ }^{2}\right.
$$

where for country $i, v$ is the overall variance of $\log$ wages; $\alpha$ is the fraction of workers unionized; $v_{\mathrm{a}}$ and $v_{n}$ are the variance of $\log$ union and nonunion wages; $w_{2}$ and $w_{n}$ are average $\log$ union and nonunion wages; and $w^{*}$ is the country's average log wage level.?

By the accounting scheme in equation (1), there are several routes through which the industrial relations system can affect overall wage inequality. First, unions typically raise their members' relative wages. This effect alone could increase or decrease overall wage dispersion, depending on where union workers would have been in the wage distribution in the absence of unionism. However, as suggested by the final two terms in equation (1), in an accounting sense, it is the union-nonunion wage gap (not controlling for other wageinfluencing factors) itself that is important in "explaining" the overall variance. All else equal, the larger this gap, however it is achieved, the larger the country's overall wage variance will be. And our data show that this gap is much higher for the U.S. than other countries. ${ }^{10}$

Second, unions typically negotiate contracts that allow for less variation in pay than occurs in the nonunion sector (Freeman, 1982; Blanchflower and Freeman, 1992). Unions are

9 Freeman (1980) uses such a decomposition to assess the role of unionism on U.S. wage inequality. See also Juhn, Murphy and Pierce (1993) who employ a similar appraach to measuring the impact of industry on wage inequality.

10 Much of this higher U.S. union-nonunion wage differential is due to a higher ceteris paribus U.S. union-nonunion wage gap rather than to differences in the personal characteristics of union and nonunion workers (Blanchflower and Freeman, 1992). Thus, a strong causal role for the industrial relations system is suggested. 
much less prevalent in the U.S. than elsewhere; thus the lower union variance in pay would get a smaller weight in equation (l) in the U.S. Hence, we would expect a higher overall variance in wages in the U.S. even if the variance of wages within the union and nonunion sectors were identical across countries. However, there are strong reasons for expecting both of these within sector variances to be higher in the U.S. than elsewhere. These higher within sector variances constitute a third route by which the U.S. industrial relations system raises wage inequality relative to other countries.

With respect to the union sector, collective bargaining in the U.S. is relatively decentralized, with an emphasis on single-firm agreements which, in most cases, are not firmwide (Hendricks and Kahn, 1982). In contrast, as discussed below, in most of the other countries in our sample, bargaining is conducted on an industry-wide or even an economywide level. Thus, there appears to be more scope for interfirm and interindustry wage differentials in the U.S. than in other countries; and a substantial portion of the wage inequality we observe in the U.S. is associated with such firm or industry wage effects (Blau, 1977; Groshen, 1991; Davis and Haltiwanger, 1991; Krueger and Summers, 1988).

While a lower variance in the union sector of other countries could be achieved either by raising the bottom, restraining the top, or both, centralized bargains often emphasize the setting of wage minima across diverse units. For example in Austria, Germany, Italy, Sweden and Switzerland (as well as in several European countries outside our sample), collective bargaining agreements, generally at the industry level, set minimum rates for the lowest pay group in a collective agreement (EIRR, Oct. 1992). Such minima, to the extent they are binding, will tend to disproportionately bring up the floor among workers covered by the contract. In the limiting case, a contract that covered all workers in the economy might be expected to compress the bottom of the distribution, just as would a high national minimum wage. Thus, we expect to find greater narrowing at the bottom than at the top in the union sector in most countries compared to the U.S., but regard this as to some extent an empirical question.

DNTAGE2.DOC 2202914 3:28 PM 
Several factors also lead us to expect more dispersion of nonunion wages in the U.S. than elsewhere. These include the practice in many other countries of extending the terms of collective bargaining agreements to nonunion workers. Such contract extensions blur the distinction between union and nonunion wage-setting in these countries. To the extent that unions in all countries tend to compress wages at the bottom in the union sector, contract extension will not only reduce wage variation in the nonunion sector, but compress wages at the bottom as well. In addition, the higher degree of union organization outside the U.S. should produce more "voluntary" imitation of union pay structures by nonunion firms than in the U.S. ${ }^{11}$ Finally, the impact of these factors has been further strengthened by explicit union and govemment policies in some countries to bring up the bottom of the wage distribution.

\section{Overview of International Differences in Labor Market Institutions}

In this section, we provide a brief review of the institutional arrangements goveming wage determination in the countries in our sample which suggests that wage-setting is indeed more decentralized in both the union and nonunion sectors in the U.S. Looking first at the union sector, Sweden and Norway exemplify the highest degree of centralization of wagesetting in these countries. There, the major union federation (LO) signs an agreement with the employer association (SAF) covering a major portion of the labor force (Leion, 1985;

Thorsrud, 1985). Austrian collective bargaining is also very centralized, with agreements in most cases covering an entire industry or group of industries throughout the country (Tomandl and Fuerboeck, 1986). In Germany, contracts usually cover all employers in an industry in a state, providing a higher degree of centralization than in the U.S. but probably less than in Scandinavia or Austria (Kennedy, 1982). And in Italy, master industry-wide agreements

11 This will be the case if union "threat" effects dominate any negative "crowding" effects in the nonunion sector caused by the adverse employment effects of unionism. Kahn and Curme (1987) found for the U.S. that, other things equal, nonunion wage dispersion was lower in
highly unionized than in less unionized industries. 
negotiated at the national level between unions and employer associations have traditionally been the norm (Katz, 1993). Collective bargaining in Australia has also been characterized by considerable centralization, as the system heavily relies on government tribunals and compulsory arbitration in setting wages (Katz, 1993). It has been estimated that about 90 percent of the Australian labor force has its pay set by these tribunals (Killingsworth, 1990). Hungary was surveyed during the period of Communist party rule. While most workers were in unions, wages were controlled by the state, providing another example of centralized wage determination (Rezler, 1972-3; U.S. Department of Labor, 1992). For each of these countries, we would expect less dispersion of union wages than in the U.S.

Collective bargaining in Switzerland and Britain is less centralized than in Scandinavia, Austria and Germany, but likely more centralized than in the U.S. While Britain, like the U.S., had a mixture of single-firm and multiemployer agreements, in the 1970s, the latest period for which quantitative data are available, bargaining appeared to be more centralized in Britain. In the U.K. for 1977-78, 25 percent of manufacturing contracts covered more than one firm (Deaton and Beaumont, 1980), while for the U.S. the figure in 1975 was only 13 percent (Hendricks and Kahn, 1982). Switzerland appears to have a mix of centralization and decentralization. On the one hand, many agreements exclude the subject of pay, leaving it to individual determination. On the other hand, there are no antitrust laws, and parties are encouraged to form associations, leaving open the possibility of de facto centralization (Wrong, 1987). Further, it has been estimated that about haif of the Swiss private sector work force is covered by industry collective bargaining agreements (EIRR, Oct. 1992).

Events in the 1980s and 1990s have led to the decentralization of bargaining in virtually every industrialized country. ${ }^{12}$ In Scandinavia, the influence of the central SAF-LO agreement was reduced starting in the 1980s. In Australia, tribunal decisions have allowed

12 This discussion of recent trends is based on Katz (1993) and Edin and Holmlund (forthcoming). 
more interfirm variation in wage settlements. In Germany and Italy, bargaining has shifted in some cases from the industry to the plant level in the late 1980s. In Britain and the United States, multiemployer units continued to crumble in the 1980 s and 1990 s.

We have no way of knowing whether decentralization has proceeded faster outside the U.S. than inside. Nonetheless, one's impression is that, with the possible exception of Britain, systems of collective bargaining remain more centralized in the other countries than in the United States. The U.S. does not have the centralizing institutions that are still in place in these other countries. And deunionization proceeded much more rapidly in the U.S. than in other countries (including Britain), providing an extreme form of decentralization (Blanchflower and Freeman, 1992; Katz, 1993).

The structure of collective bargaining thus leads us to expect more dispersion of union wages in the U.S. than elsewhere. A review of labor market institutions in other countries leads us to expect more dispersion of nonunion wages in the U.S. as well. In Australia, wage tribunals set minimum pay rates across both the union and nonunion sectors, while in then Communist Hungary, wages in both sectors were controlled by the state. In Germany, Austria, Italy, and Switzerland, the government routinely extends the terms of collective bargaining agreements to nonunion workers. ${ }^{13}$ It has been estimated that as of 1992 , legally binding industry or sectoral level agreements covered 90 percent of workers in Germany, 98 percent in Austria, "the vast majority" in Italy, and "nearly all" workplaces in Sweden (EIRR, Oct. 1992). In Switzerland, in 1992, roughly 10 percent of all workers (or about 20 percent of nonunion workers) were nonunion employees whose wages had been set through contract extensions (EIRR, Oct. 1992). These figures for 1992 suggest that whatever trends there have

13 See Kennedy (1982), Tomandl and Fuerboeck (1986), Treu (1990), and EIRR (Oct. 1992). A sizable proportion of Italian workers are self-employed or work in an underground or informal sector in which government-mandated benefits are not paid. The self-employed are not included in our analysis due to our interest in the wage determination process for wage and salary workers. Further, it is likely that since informal sector employment is illegal, it is underreported by the respondents in our survey-based data. Thus, we may understate wage
inequality in Italy. 
been toward decentralization in the 1980 s and 1990s, wage setting remains considerably more centralized in Western Europe than in the U.S.

Finally, in Sweden, Italy, and West Germany, explicit union and government policies have been followed that would be expected to lead to strong compression at the bottom of the distribution. From 1968 to 1974 , the $\mathrm{LO}$ in Sweden made a conscious effort to raise the relative wages of lower-paid workers, leading to a sharp fall in inequality (Edin and Holmlund, 1992). In Italy, the wage indexation system, the scala mobile, in place from 1975 to 1992, gave across-the-board lira increases in wages in response to inflation. The system was designed to reduce skilled-nonskilled pay differentials (EIRR, Aug. 1992; Treu, 1990). By 1990, Italian employers claimed that accumulated indexation payments accounted for 40 percent of labor costs (EIRR, Jan. 1990). While other aspects of the pay package to some degree counteracted the leveling effects of indexation, Erickson and Ichino (forthcoming) found that the system still had some independent effect in reducing inequality. Finally, in recent years in Germany, some unions have succeeded in getting above sectoral levels of wage increases for low paid workers, in an attempt to raise the floor (EIRR, Nov. 1992).

\section{Results}

\section{A. Data Sources and the Definition of Hours-Corrected Earnings}

We compiled micro-data from several sources to examine international differences in male wage inequality. First, we used the International Social Survey Programme (ISSP) for the following countries and time periods: Austria (1985-87 and 1989), West Germany (198588), Hungary (1986-88), Switzerland (1987), Britain (1985-89), the United States (1985-89), and Norway (1989). Second, we supplemented the ISSP with several other micro-data bases in order to expand our coverage of countries. Specifically, we used the Class Structure and Class Consciousness (CSCC) data base compiled by Erik Wright for Sweden (1980) and Norway (1982); the Income Distribution Survey (IDS) for Australia (1986); and a Bank of 
Italy (BI) survey for Italy (1987). ${ }^{14}$ Third, we performed a special comparison for 1984 between the U.S. and Sweden using two additional data bases with more detailed information on personal characteristics and eamings, the Michigan Panel Study of Income Dynamics (PSID) and the Swedish Household Market and Nonmarket Activities Survey (HUS). ${ }^{15}$ In this portion of the analysis, the sample is restricted to full-time workers and, in the case of the U.S. data, to whites. White males are used instead of all males in order to produce a relatively homogeneous U.S. sample to compare with the Swedish data. (The ISSP did not collect information on race.)

The specific eamings measures used in the data for each country are described in detail in the Appendix. For all cases except the 1984 Sweden-U.S. comparison, the earnings figure is expressed on an annual or monthly basis. The computation of wage rates from such data is complicated by the omission of information on annual weeks worked. ${ }^{18}$ Data on weekly hours worked are available, however, allowing for some adjustment of eamings for time input (described below). For the 1984 Sweden-U.S. comparison, we are able to compute hourly earnings.

With the exception of the 1984 HUS (Sweden) and PSID (U.S.), the earnings variable was generally coded into categories. ${ }^{17}$ In the analyses presented below, we arbitrarily coded

14 For descriptions of these data, see Blanchflower and Freeman (1992)--ISSP; Rosenfeld and Kalleberg (1990)-CSCC; Blackbum and Bloom (1991)-IDS; and Erickson and Ichino (forthcoming)--BI. The ISSP had information on Italy, but it did not collect data on the respondents' industrial sector. We therefore used the BI data instead. Further, preliminary results indicated that the Australian data in the ISSP were inconsistent with other sources, leading us to use the more consistent IDS data.

15 For a description of the PSID, see Blau and Kahn (1993), and for information on the HUS, see Edin and Holmlund (forthcoming).

16 For Australia and for a subset of the 1982 Norway data, weeks worked information is available. However, we treat these countries similarly to the others in order to maintain comparability.

17 The Australian eamings data were originally reported as a continuous variable. However, to maintain comparability with the other countries, we recoded the Australian eamings into the ISSP's intervals for Australia. When the analysis was performed for Australia using the original continuous variable, the results were virtually identical to those reported here. The BI 
the top (open-ended) category as 1.2 times its minimum value. Our results were not sensitive to assumptions about top-coding. Finally, concern about adequate sample size led us to pool years of data for those ISSP countries surveyed more than once (see above). However, since the multiple years of data on Sweden and Norway come from different sources, we do not pool them.

The hours-corrected earnings variable shown in Figure 1 is computed as follows. For each country, the following regression was estimated:

$$
\operatorname{InEARN}=b_{0}+b_{1} \text { PART }+b_{2} \text { HPART }+b_{3} H F U L L+B^{\prime} X+c,
$$

where lnEARN is the log of earnings; PART is a dummy variable for part-time work (less than 35 hours per week); HRPART and HRFULL are interactions of weekly work hours with part- and full-time status; $\mathbf{X}$ is a vector of explanatory variables including years of schooling, potential experience and its square, a dummy variable for those married, spouse present, a union membership dummy variable, one-digit industry and occupation dummies, and year dummies for the countries for which we pooled different years of data; and $\mathrm{e}$ is an error term. (See Appendix Table A-1 for variable definitions.) ${ }^{18}$

The PART, HRPART, HRFULL and year dummy variable coefficients from (2) were used to adjust each person's eamings for work hours and year by assuming a 40 hour work week and the end year of the pooled years. That is, for each worker $i$, we have:

data were also continuous but did not match up with the ISSP categories for Italy. We therefore used the continuous earnings variable for Italy.

18 Marital status was not available for Italy; union status was not available for Australia or Italy. For the purpose of comparing the U.S. to these countries, we estimated U.S. equations that conformed to the same specification as each country. In analyses of the U.S. PSID and the Swedish HUS data shown below, actual labor market experience is used; union status is not available in the HUS. 
where YFULL is the log of hours-corrected earnings, the b's are estimated coefficients, and $\tau_{t}$ and $Y R_{t}$ are, respectively, estimated coefficient and dummy variable vectors referring to the pooled years of data. For the 1984 U.S.-Sweden comparison, the earnings variable is hourly eamings, based on the previous year's eamings divided by the previous year's work hours. ${ }^{19}$

Measures of inequality calculated on the basis of hours-corrected eamings were presented in Figure 1 and are also shown in Panel A of Table 1. We again see that the U.S. has a considerably larger standard deviation of eamings and 90-10 gap than the other countries. However, whereas the U.S. 50-10 eamings differential is much larger than it is in the other countries ( $0.582 \log$ points above the nonU.S. average), the $90-50$ differential in the U.S. is smaller than in Britain, Switzerland and Hungary and only slightly larger than in Germany, Austria, and Norway (1989); the U.S. 90-50 gap and is only slightly (0.007 log points) larger than the unweighted average for the other countries. Similar results are obtained for a comparison of log hourly eamings between the U.S. and Sweden in 1984 (Panel B). The U.S. 50-10 differential is much larger (0.518 log points) than it is in Sweden, while the 90-50 gap is only $0.158 \mathrm{log}$ points higher.

\section{B. The Role of Prices and Measured Characteristics}

A crucial question raised by the results shown in Table 1 is the degree to which the observed differences in wage dispersion between the U.S. and other countries are due to differences in measured characteristics versus differences in the prices of labor market skills (i.e., wage structure). To shed light on this issue, we employ a full distributional accounting

19 For the U.S. PSID sample, we excluded anyone eaming less than $\$ 1$ per hour or more than $\$ 250$ per hour in 1983 dollars. The U.S. minimum wage was $\$ 3.35 / \mathrm{hr}$ at the time. For Sweden, we excluded anyone eaming less than 7 kroner per hour, or about $1 / 7$ the average measured wage. This exclusion restriction was made since $\$ 1$ was about $1 / 7$ the U.S. average. Since the U.S. wage distribution is more dispersed than the Swedish, any error caused by these exclusion restrictions will lead us to understate the Swedish-U.S. difference in wage
dispersion. 
scheme developed by Juhn, Murphy and Pierce (1993) to study intertemporal changes in U.S. wage inequality.

We begin with a wage equation for worker $i$ in country $j$ :

$$
\text { YFULL }_{i j}=\beta_{j} Z_{i j}+\sigma_{j} \theta_{i j}
$$

where YFULL is hours-corrected (and year-corrected) log earnings (or hourly eamings for the 1984 Sweden-U.S. comparison), $Z$ is a vector of measured characteristics, B is a vector of coefficients, $\theta$ is a standardized residual with mean 0 and variance 1 , and $\sigma$ is the residual standard deviation of log hours-corrected earnings.

The first hypothetical distribution for country $j$ is the set of wages that would emerge if we applied the estimated U.S. wage function $\left(\beta_{W}\right)$ and residual standard deviation $\left(\sigma_{w}\right)$ to each worker $i$ in country $j$ :

$$
\mathrm{Y}(1)_{\mathrm{ij}}=\beta_{\mathrm{u}} \mathrm{Z}_{\mathrm{ij}}+\sigma_{\mathrm{u}} \theta_{\mathrm{ij}}
$$

$\mathrm{Y}(1)_{\mathrm{ij}}$ is computed for each worker in country $\mathrm{j}$ by valuing his measured characteristics at the U.S. coefficient vector $\beta_{U}$ and his position in his own country's wage residuals (e.g. the 35th percentile) at the corresponding position in the U.S. residual distribution. The primary difference between the distribution of YFULL for the United States and of Y(1) for country $j$ is the substitution of country $\mathrm{j}$ 's distribution of measured characteristics for those of the U.S. in the U.S. wage equation. ${ }^{20}$ Construction of $Y(1)$ is important because it allows us to

$20 \mathrm{Y}(1)_{i j}$ also uses country j's estimated values of $\theta$, but these are standardized across countries and therefore do not directly contribute to international differences in the distribution of wages. However, to the extent that $\theta$ is more strongly correlated with $Z$ for one country than another, the difference between the distribution of YFULL $y$ and $Y(1)_{j}$ will also reflect the effects of this difference in correlation. We discuss differences in unmeasured productivity characteristics below. 
determine the extent to which international differences in the distribution of wages are due to differences in the distribution of measured characteristics.

The second hypothetical distribution for country $\mathrm{j}$ results from giving each person in country $\mathrm{j}$ his own country's estimated wage coefficients but the U.S. wage residual corresponding to his position in his own country's residual distribution:

$$
\mathrm{Y}(2)_{\mathrm{jj}}=\beta_{\mathrm{j}} \mathrm{Z}_{\mathrm{ij}}+\sigma_{\mathrm{u}} \theta_{\mathrm{jj}}
$$

The difference between the distributions of $Y(2)_{i j}$ and $Y(1)_{i j}$ is entirely due to the difference between country $j$ 's wage function and that of the United States.

Finally, the impact of wage residuals on country $j$ 's wage distribution relative to that of the U.S. is the difference between the distribution of YFULL $L_{i j}$ and $Y(2)_{i j}$. We would like to interpret this as the effect of unmeasured prices (i.e. the difference between $\sigma_{\mathrm{u}}$ and $\sigma_{\mathrm{j}}$ ). However, it also includes the effect of differences in the distribution of unmeasured productivity characteristics. For example, while the U.S. residual distribution may be more dispersed than that of other countries because of higher prices of unmeasured skills, it may also be the case that the U.S. labor force is more diverse in its unmeasured characteristics. This latter difference would be included in our estimate of the effect of wage residuals, but does not reflect unmeasured prices. Our review of the literature on wage-setting institutions suggests that the U.S. does in fact have higher skill prices than other countries; but we cannot rule out the possibility that some portion of the cross-country differences in wage variation associated with the wage residuals reflects intemational differences in unmeasured quantities as well as unmeasured prices.

To further support the notion that unmeasured prices are important, we supplement our other analyses with a comparison of 1984 data from the U.S. PSID and the Swedish HUS which is likely to be less contaminated by unmeasured heterogeneity than our other data sources. Specifically, as noted above, for the 1984 U.S.-Swedish comparison, we use a 
sample of white, full-time employed men from the U.S. and full-time employed men from Sweden. Thus, racial heterogeneity in the U.S. will not directly affect this comparison. In addition, we are able to construct actual average hourly eamings in these samples, again reducing the scope for errors. Finally, we are able to control for actual, rather than potential labor market experience. While potential labor market experience is a good proxy for actual experience for men, fewer errors will result if one has data on the real thing and if these data are themselves accurate. ${ }^{21}$

We perform the decomposition of differences in the wage distribution implied by equations (4)-(6) in two stages. Initially, we include in $Z$ a vector of human capital characteristics (education, potential experience and its square, and marital status). Next, we augment the human capital variables with a vector of industry and occupation dummy variables and union status; i.e., we estimate equation (2) above. A comparison of the results from the two specifications sheds light on the role of occupation, industry, and unionism in explaining the international differences.

The results of performing this decomposition for the standard deviation of log wages are shown in Table 2. Panel A of the Table shows the human capital specification results, while Panel B shows the findings for the full specification. The actual U.S.-country $j$ differences are shown in the first column. As may be seen in the second column of the Table, the distribution of measured characteristics explains relatively little (about 6 percent, on average) of the higher variation in wages in the U. S. than elsewhere under either specification. In contrast, prices appear to be important in explaining the differences in inequality between the U.S. and the other countries. In every instance, measured prices and residual effects serve to raise the U.S. standard deviation of wages compared to each country.

21 In the Swedish data, information on actual experience since age 16 is collected, while in the PSID, the variable refers to years of experience since age 18. To make the two variables comparable, we added two times the U.S. white male employment/population ratio for ages 16-17 to the PSID experience figure. These data were collected from USBLS (1985). 
Table 2 indicates that prices of measured characteristics explain a larger share than does the distribution of measured characteristics -15 to 20 percent on average, with the bulk of the difference between the U.S. and the other countries (74. to 79 percent) attributable to the larger residual variation of wages in the U.S. Thus, prices of labor market skills (both measured and unmeasured) appear to be the primary cause of the higher variation in wages in the U.S., although we cannot rule out the possibility that the distribution of unmeasured characteristics also plays a role. The 1984 U.S.-Sweden comparison is instructive in this regard. Despite the more homogeneous U.S. sample and the better measure of wages and experience, the results are quite similar to the 1980 U.S.-Sweden comparison. Most notably, measured characteristics actually play a smaller part in explaining the U.S.-Swedish difference in the 1984 comparison.

We explicitly compare the magnitude and sources of the $50-10$ and the $90-50$ differentials in Table 3. The results for the human capital specification are again shown in Panel A and the results for the full specification in Panel B. The first column of both Panels shows the actual U.S.-country $j$ difference in the 50-10 and 90-50 log wage differentials. As we saw above, these differences are considerably greater for the 50-10 gap (0.576 log points, on average) than for the $90-50$ gap (0.021 log points, on average). 22 . The second column of Table 3 shows that these 50-10 vs. 90-50 comparisons are substantially affected by the distribution of measured characteristics.

For each country j, the Measured Characteristics Effect is the difference between YFULL $u$ and $Y(1)_{j}$ at the indicated percentiles of the distribution. The positive effects for the 50-10 differentials for both specifications indicate that the U.S. distribution of measured characteristics widens the 50-10 gap compared to that in each country. These effects--0.245 $\log$ points for the human capital specification and $0.207 \log$ points for the full specification, on

22 Note, these figures differ slightly from those presented above because Sweden 1984 is now included in the non-US average. 
average-are large indeed. A comparison of the results for the two specifications indicates that it is the U.S. distribution of human capital characteristics that is relevant in explaining the international differences, with the U.S. distribution of industry, occupation and union status slightly lowering the 50-10 gap compared to other countries. ${ }^{23}$ On average, measured characteristics are estimated to account for 35.9 to 43.4 percent of the higher U.S. 50-10 differential. In contrast, the distribution of measured characteristics lowers the $90-50$ wage differential in the U.S. compared to other countries. In each case, the Effect is negative with an unweighted average effect of about $-0.16 \mathrm{log}$ points in both specifications. For both the 50 10 and $90-50$ analyses, we find the impact of measured characteristics to be quite similar for the Sweden 1984 and Sweden 1980 comparisons, again suggesting that greater unmeasured heterogeneity of U.S. workers is not driving our results.

The findings for the Measured Characteristics Effects imply that a considerable portion of the wider 50-10 gap relative to the 90-50 gap in the U.S. is accounted for by differences in the distribution of productive characteristics. With the same distribution of measured characteristics, the average difference between the U.S. 50-10 gap and that for the other countries would decline to 0.331 to $0.369 \mathrm{log}$ points (from 0.576 ), while the figure for the 90 50 gap would increase to about 0.18 (from 0.021 ). Thus, if we consider the part of the differential which is not accounted for by measured characteristics (i.e., the sum of the Wage Coefficients and Wage Residuals Effects) as potentially due to wage structure, we find that the U.S. wage structure widens both the top and the bottom of the wage distribution relative to other countries. In particular, adding the Wage Coefficients and Wage Residuals Effects, we find that in every case, U.S. prices lead to a widening of both the 50-10 and the 90-50 differentials compared to other countries.

23 To some degree union status, while treated here as a measured characteristic in Panel B of Tables 2 and 3 , could be considered part of the wage-setting institutions. The effects of collective bargaining are investigated in detail below. 
In the decomposition shown in Tables 2 and 3, controlling for personal characteristics is especially important, as it reveals the $90-50$ widening effect of U.S. prices, an effect that is not apparent if one merely compares the raw 90-50 differential in the U.S. with that in other countries. Further, it reduces the likelihood that we are overstating the compression at the bottom (that would occur if one merely examined the raw 50-10 differentials). However, the U.S. wage structure continues to widen the bottom by more than the top. This is true on average and in nine (Full Specification) or ten (Human Capital Specification) of eleven possible cases. Such an effect is consistent with government and trade union wage policies in other countries that have their biggest effect in bringing up the bottom of the distribution.

The last two columns of Table 3 show the effects of Wage Coefficients and Wage Residuals separately. For the 50-10 gap, the U.S. human capital wage coefficients usually have a small widening effect compared to the other countries (accounting for 4.2 percent of the difference, on average), although the effect is negative in four cases. The Coefficients Effect is notably increased when the full specification is employed (accounting for 21.7 percent of the difference, on average), suggesting that it is the prices associated with the industry, occupation and unionism variables that are particularly high in the U.S. In both specifications, however, the Wage Residuals Effect accounts for a substantial share (42.2 to 53.3 percent) of the U.S.country $j$ difference. In the case of the $90-50$ gap, the Coefficients and Residual Effects are generally positive and do not differ very much between the two specifications. This suggests that the impact of measured prices primarily reflects higher prices of the human capital variables in the U.S. The Coefficients and Residual Effects are of roughly equal size, on average.

\section{The Effect of Institutions: Collective Bargaining and Contract Extension}

In our discussion of trade unionism, four important points were emphasized that each leads us to expect a higher wage dispersion in the U.S. than in other countries. First, the U.S. is less unionized, implying a relatively smaller low variance sector. Second, the union- 
nonunion wage differential is larger in the U.S. Third, collective bargaining is more centralized in other countries than in the U.S. Fourth, in several countries, the terms of collective bargaining agreements are commonly extended by law to nonunion workers, a feature not present in the U.S. industrial relations system. In addition, the extent of voluntary emulation of union pay structures by the nonunion sector (i.e., spillover effects) is likely to be greater in other countries than in the U.S. due to their larger union sectors.

These latter two aspects of wage-setting lead us to expect lower wage dispersion in both the union and nonunion sectors in other countries compared to the U.S. Whether the union or the nonunion effect is larger (relative to the U.S.) is an empirical question. On the one hand, suppose that the wage spillover due to contract extension and voluntary imitation is virtually complete in the non-U.S. countries, but that unions in these countries have only a slightly greater narrowing effect for their members than U.S. unions do. Then we would expect the nonunion differences in inequality between the U.S. and other countries to be larger because, outside the U.S., workers not in unions would essentially be treated as union members. On the other hand, suppose that the spillover to nonunion workers in the non-U.S. countries is partial and that unions in these countries have a much greater narrowing effect for their members than U.S. unions do. Then U.S.-non-U.S. differences in union inequality could be greater than nonunion differences.

These issues were investigated using data on the countries in our sample for which collective bargaining status was available. Thus, Italy, Australia and Sweden 1984 were excluded for lack of data. In addition, Sweden 1980 could not be included because of the small sample of nonunion workers (59) in the data set. With a unionization rate of 85.7 percent, Sweden may be considered essentially a unionized country so that a union-nonunion comparison may not make a great deal of sense in any case.

Table 4 decomposes the intemational differences in the overall variance of wages by union status. It is constructed along the lines suggested by equation (1) and further developed in equation ( 7 ) below. 


$$
\begin{aligned}
v_{u}-v_{j} & =\left[\alpha_{a u}\left(v_{a u}-v_{a j}\right)+\left(1-\alpha_{a u}\right)\left(v_{n u}-v_{n j}\right)\right] \\
& +\left[v_{a j}\left(\alpha_{a u}-\alpha_{a j}\right)+v_{n j}\left\{\left(1-\alpha_{a u}\right)-\left(1-\alpha_{a j}\right)\right\}\right] \\
& +\left[\alpha_{a u}\left\{\left(w_{a u^{-}} w^{*}\right)^{2}-\left(w_{a j}-w_{j}^{*}\right)^{2}\right\}+\left(1-\alpha_{a u}\right)\left\{\left(w_{n u}-w^{*}{ }^{*}\right)^{2}-\left(w_{n j}-w_{j}^{*}\right)^{2}\right\}\right] \\
& +\left[\left(w_{a j}-w_{j}^{*}\right)^{2}\left(\alpha_{a u}-\alpha_{a j}\right)+\left(w_{n j}-w_{j}^{*}\right)^{2}\left\{\left(1-\alpha_{a u}\right)-\left(1-\alpha_{a j}\right)\right\}\right],
\end{aligned}
$$

where $v_{u}$ and $v_{j}$ are the overall U.S. and country $j$ variances in $\log$ wages; $\alpha_{a}$ is the fraction of workers unionized; $v_{a}$ and $v_{n}$ are the variances of union and nonunion $\log$ wages; $w_{a}$ and $w_{n}$ are average union and nonunion $\log$ wages; and $w^{*}$ is the overall average log wage.

The first square-bracketed term of $(7)$ is the Within-Sector Variance Effect which measures the contribution to the overall wage variance difference of U.S.-country $j$ differences in variances within the union and nonunion sectors. The second square-bracketed term of $(7)$ is the Within-Sector Composition Effect which measures the contribution to the overall wage variance difference of U.S.-country $j$ differences in the representation of workers in the high variance sector. The third square-bracketed term of $(7)$ is the Between-Sector Wage Differential Effect which measures the contribution to the overall wage variance difference of relatively high union-nonunion wage differentials in one country. Finally, the last squarebracketed term of $(7)$ is the Between Sector Composition Effect which measures the contribution to the overall wage variance difference of a higher representation of employment in the sector with wages relatively far from the average.

Table 4 indicates that the overwhelming portion of the gap between the U.S. and other countries in the variance of wages-on average, about 86 percent $(0.3320 / 0.3881)$--is due to higher U.S. variances within the union and nonunion sectors. Another substantial proportion, about 12 percent of the average U.S.-country $j$ gap in variances, comes from the Within-Sector Composition Effect. That is, a higher proportion of U.S. workers are nonunion, and this is the sector with a larger variance in all countries. The higher union-nonunion wage differential in the U.S. causes a small widening of the U.S. variance relative to other countries, with the 
Between-Sector Wage Differential Effect accounting for, on average, about 2 percent of the average U.S.-other country variance gap. Finally, the Between-Sector Composition Effect is found to be negligible.

Table 4 implies that the key to understanding U.S.-other country differences in wage inequality is explaining inequality within the union and nonunion sectors. We begin such an analysis in Table 5, which provides summary measures of union and nonunion wage inequality. With the exception of Hungary, wage inequality, as measured by the standard deviation of the log of wages, is smaller in the union than in the nonunion sector of each country. For the most part, this is associated with smaller 50-10 and 90-50 gaps in the union sector. While the U.S. conforms to this general pattern, the standard deviation of wages is greater in both the union and nonunion sectors in the U.S. than elsewhere. And the average U.S.-other country differences are similar: $0.259 \mathrm{log}$ points for union workers $(0.633-0.374)$ and $0.270 \log$ points for non union workers $(0.799-0.529)$. However, mirroring the aggregate patterns, while the 50-10 gap is larger in both the union and nonunion sectors in the U.S. than in each of the other countries, the $90-50$ gap is about the same (nonunion sector) or smaller (union sector) in the U.S. Thus, in a descriptive sense, what distinguishes the U.S. wage distribution from that of other countries in both sectors is the greater spread at the bottom. Moreover, the U.S.-country $j$ difference in the 50-10 gap is much larger, on average, for the nonunion sector $(0.566 \log$ points) than the union sector $(0.285 \log$ points $)$, and in every case, the intercountry difference is larger for nonunion than union workers.

Together, Tables 4 and 5 suggest that the higher overall U.S. wage variance is due to a higher wage variance within both the union and nonunion sectors in the U.S. Moreover, the higher U.S. variance within each sector is associated with a larger 50-10 gap in both sectors in the U.S. than elsewhere, with the U.S-country j difference in the 50-10 gap being larger for the nonunion than for the union sector. This is suggestive of larger union spillover effects on nonunion wage structures in other countries than in the U.S., although it could still be due to the impact of measured characteristics. In order to shed light on the impact of prices as 
opposed to the distribution of measured skills, we perform the regression-based decomposition outlined in equations (4)-(6) separately for union and nonunion workers in each country using the full specification. That is, we employ the overall regressions for the full specification to obtain the estimated coefficients, but then examine the distributions of YFULL, $Y(1)$ and $Y(2)$ separately for union and nonunion workers. 24

The results of performing this decomposition for the standard deviation of wages, and the 50-10 and 90-50 differentials are shown in Table 6. In each case, we present the overall U.S.-country j difference, the Measured Characteristics Effect, and the Wage Structure Effect (i.e., the sum of the Coefficients and Residual Effects). The findings for the Wage Structure Effect indicate what the U.S.-country $j$ difference would be after adjusting for differences between countries in the distribution of measured characteristics. Our discussion of institutions implies that these labor market prices would lead to a higher dispersion of both union and nonunion wages in the U.S. than elsewhere. Looking first at the standard deviation of $\log$ wages, we find that it continues to be substantially higher in the U.S. in both the union and nonunion sectors even after taking into account the distribution of measured characteristics. The wage structure effect is positive (i.e. the U.S. structure raises the standard deviation of the log of wages compared to other countries) in each instance. Moreover, in each case, the U.S.-country-j difference is larger for the nonunion than for the union sector: the Wage Structure Effect is 0.337 for nonunion workers, on average, compared to 0.243 for union workers. This same pattem obtains for the 50-10 differential: the U.S. gap remains larger than that elsewhere in both sectors after adjustment for the distribution of characteristics, with the U.S.-country $j$ difference being considerably larger, on average, for nonunion than for union workers (i.e., 0.423 versus $0.284 \log$ points). The effect is larger for nonunion workers in five of seven possible comparisons. In contrast, while the U.S. does tend to have a larger 24 Ideally one would like to estimate separate union and nonunion equations to allow the
coefficients to vary across sectors, but, unfortunately, small sample sizes precluded this
approach. 
90-50 gap than elsewhere after adjustment for the distribution of measured characteristics, the difference between the U.S. and the other countries is smaller and tends to be about the same size in the nonunion as in the union sector (i.e., 0.192 versus 0.166 log points, on average). The nonunion effect is larger than the union effect in four of seven cases.

Thus, after controlling for the distribution of measured characteristics our central conclusions remain the same: the variance of wages is greater within the nonunion and union sectors in the U.S. than elsewhere, with the wage structure in other countries tending to be considerably more compressed at the bottom in both sectors. Moreover, we now find that both of these features are more pronounced for the U.S. nonunion sector than for the union sector. These findings are consistent with a considerably more decentralized wage-setting process in the U.S. union sector and the absence in this country of contract extension and other mechanisms which extend union-determined wages to the nonunion sector. Evidently, the spillover from union to nonunion wage structures in the other countries is strong enough to outweigh the direct effects of centralized bargaining on union workers' wage dispersion.

An additional implication of the wage compression-contract extension phenomenon is that the union relative wage effect (i.e., union wages compared to nonunion wages, all else equal) should be higher in the U.S. than in other countries. Further; this effect should be especially high for U.S. Unskilled workers compared to unskilled workers in other countries. That is, unions in all countries may be expected to raise the wages of low skill more than those of high skill workers; however, outside the U.S., these effects are transmitted to nonunion workers to a much greater extent. To probe for the consistency of our findings with this institutional view, we perform quantile regression analysis for each country. This technique allows one to analyze given portions of the wage distribution (e.g., the 10th, 20th, or 50th percentile) conditional on a set of personal characteristics Z. ${ }^{25}$

25 For further discussion of the quantile regression technique, or Chamberlain (1991). 
Suppose, for example, that we can express the qth percentile of this conditional distribution for country $j$ as:

$$
\text { YFULL } L_{q} \mid Z=B_{q} Z
$$

where YFULL $_{\mathbf{q}} \mid Z$ is the qth percentile of the conditional distribution of hours-corrected eamings given $Z$, and $B_{q}$ is a vector of quantile regression coefficients. Since union membership is an element of $Z$, we can make inferences about the impact of unions on the wage distribution by comparing the union quantile regression coefficients at different portions of the conditional distribution of wages given $Z$. An additional benefit of using quantile regressions is that we no longer need to assume comparability in the explanatory variable definitions across countries, as we did in the decompositions in Tables 2,3 and 6. For example, in these earlier analyses, we treated a year of schooling as comparable across countries. In the quantile regression analysis, we merely ask, within each country, what the union-nonunion pay gap is for workers at different points of the wage distribution, controlling for education level (and other explanatory variables).

Table 7 provides union membership coefficients from quantile regressions of the form of equation (8) with the full specification. The Table indicates that, at each point of the distribution, the U.S. ceteris paribus union-nonunion wage differential is larger than elsewhere. The finding of a larger union premium in the U.S. also characterized our Ordinary Least Squares (OLS) results and has been obtained in previous OLS analyses (Blanchflower and Freeman, 1992). It is strongly suggestive of contract extension and other mechanisms by which union wages in other countries "spill over" into the nonunion sector thus lowering their estimated ceteris paribus union-nonunion differentials relative to the U.S.

Second, within virtually every country, the union wage effect is larger for the lower quantiles of the distribution. This is consistent with union pay-leveling effects--being in a union matters more for one's wages the lower down one would have been in the nonunion

INTWAOEZ.DOC 2/20294 3:31 PM 
wage distribution. This finding has been obtained in quantile regressions on U.S. data (Chamberlain, 1991). However, the decline in union effects as we move up the wage distribution is steeper in the U.S. than elsewhere. For example, in the U.S., the ceteris paribus union-nonunion pay gap at the 10th percentile is 0.363 and declines to 0.176 at the median-a decrease of $0.187 \log$ points. In contrast, the nonU.S. average union premium is 0.102 at the 10 th percentile and falls to 0.016 at the median, a drop-off of $0.086 \mathrm{log}$ points. Thus it appears that union pay policies that bring up the bottom of the union wage distribution are common to all countries, including the U.S. The difference between the U.S. and the countries observed here is that, in those countries, such policies are extended to the nonunion sector to a greater extent. The use of quantile regression increases our confidence that the 5010 findings in Table 6 actually reflect pay-setting institutions rather than the impact of measured characteristics.

The effects of union status continue to decline in almost every case as we proceed from the 50th percentile to the 90th percentile. The decline for the U.S. is $0.053 \mathrm{log}$ points, and the average for the other countries is $0.029 \mathrm{log}$ points. These are, in both cases, much less dramatic than the decreases from the 10th to the 50th percentiles, again suggesting that unions place particular emphasis on bringing up the bottom relative to restraining the top.

\section{An Alternative Explanation: Supply and Demand Effects}

The findings in Tables 2 and 3 indicate that prices of labor market skills play an important role in explaining international differences in inequality, since intemational differences in the distribution of measured characteristics do not account for the differences in wage equality. While the results presented in Tables 4-7 suggest that differences between countries in union pay-setting institutions are consistent with the observed pattems of wage inequality, we must also consider the possibility that supply and demand forces in the labor market are equally consistent. 
To investigate the impact of supply and demand, we divide each country's labor force into three skill groups. To do this, we first pool the entire sample and estimate the following wage equation:

$$
\text { YFULL }=d_{0}+d_{1} E D+d_{2} E X P+d_{3} E X P S Q+E^{\prime} C+\epsilon,
$$

where ED is education, EXP and EXPSQ are potential experience and its square, $\mathrm{C}$ is a vector of country dummies, and $\epsilon$ is an error term. ${ }^{20}$ The estimated coefficients from equation (9) were used to compute SKIIL, a predicted wage for each person in each country j:

$$
S K \Pi L L_{i j}=d_{0}+d_{1} E D_{i j}+d_{2} E X P_{i j}+d_{3} E X P S Q_{i j} \text {, }
$$

This predicted wage is a measure of the person's skill based on a world-wide pooled regression including only productivity characteristics (and eliminating country shift-terms).

We then divide each country's work force into three skill groups based on the following percentiles of SKIIL: 0-33, 33-67, 67-100. ${ }^{27}$ These percentiles are computed in two ways. First, we construct a set in which the percentiles refer to the country's own distribution of SKIIL, so that the skill groups will be of the same relative size across countries. This sample considers skill to be a relative concept, with, say the 33rd percentile of SKILL in one country considered comparable to the 33rd percentile of SKIIL in another country. One cannot analyze the effects of relative supply among these groups, since, by construction, they are all

20 Equation (9) was run using weighted least squares with the weights being (EMP/Sample Size), where EMP is average male employment in the country for the years in question and Sample Size is the size of the microdata sample for the given country. In effect, we weight by the world-wide likelihood that each worker is a member of the sample. Employment information was taken from ILO (1991). The results were similar when unweighted
regressions were used.

27 The intervals are closed at the bottom and open at the top, except for the 67-100 group, which is closed at each end. 
proportionally the same size. Second, we construct a set of skill groups based on the U.S. cutoffs for SKILL. These percentiles consider skill to be an absolute concept: for example, those who place below the cutoff for the 33rd percentile of the U.S. distribution of SKILL in one country are considered comparable to those who place below this level for the SKILL variable in another country. The relative sizes of the three groups can differ across countries under this latter definition. A similar analysis is performed separately on the 1984 PSID and 1984 Swedish data sample.

Table 8 provides information on wage differentials by skill group. Panel A compares skill groups based on own country cutoffs, while Panel B uses U.S. skill-group cutoffs. In both cases, the findings are similar to those obtained when we simply compared wage distributions. In particular, there is a larger pay gap between the middle-(33-67) and low- $(0-$ 33) skill groups in the U.S. than in each of the other countries. In contrast, the gap between high-and middle-skill groups tends to be fairly similar in the U.S. as in the other countries: the U.S. gap is about the same as the non-U.S. average when own country cutoffs are used; and slightly smaller than the non-U.S. average when the U.S. cutoffs are employed. Looking from the top to the bottom, the high $(67-100)$ vs. low (0-33) gap is, with only one exception (Switzerland using the U.S. cutoffs), larger in the U.S. than in each of the other countries. For the 1984 U.S.-Sweden comparison, the results are roughly similar when the relative cutoffs are used in that the U.S.-Swedish difference is considerably larger for the low-middle gap than for the middle-high gap. When the absolute cutoffs are used, however, the U.S.Swedish difference between the middle-low gaps is now the same size as the difference between the middle-high gaps. Regardless of the cutoff used, however, the U.S. high-low gap exceeds the Swedish high-low gap.

To analyze the impact of supply and demand, we construct supply and demand indexes by skill group for each country relative to the U.S. in a manner similar to Katz and Murphy's (1992) analysis of changes over time in U.S. inequality. We focus on the results from panel B above using the U.S. skill group cutoffs since they are more relevant for the supply indexes 
(and the net supply index which we develop below). Thus, the pattern which we seek to explain is a relatively high pay gap between the middle-and low-skill groups in the U.S. combined with a high versus middle skill differential in the U.S. which tends, with two exceptions (i.e., Sweden 1984 and Norway 1982), to be about the same or smaller than elsewhere. Despite these countervailing differences, the pay gap between the top and bottom tends overwhelmingly to be higher in the U.S.

Tuming first to demand, we wish to know whether the composition of output by industry (and the consequent derived demand for labor) favors one skill group over another in the U.S. relative to other countries. Following Katz and Murphy (1992), we construct industry-occupation cells and view the "output" of particular occupation groups as an intermediate product.

The following demand index, $\ln \left(1+\Delta D_{k}\right)$, was created for each skill group $k$ for each country relative to the U.S., where:

$$
\Delta \mathrm{D}_{\mathrm{k}}=\Sigma_{\mathrm{o}} \mathrm{c}_{\mathrm{ok}}\left(\Delta \mathrm{E}_{\mathrm{o}} / \mathrm{E}_{\mathrm{k}}\right)
$$

where o refers to occupation-industry cell, $c_{0 k}$ is skill group $k$ 's share of employment in occupation-industry cell $o$ in the U. S., $\Delta E_{0}$ is the difference between the U.S. and country $j$ 's share of total labor input employed in cell $o$, and $E_{k}$ is the U.S. share of total labor input accounted for by skill group $k$. The demand index thus measures the degree to which the occupation-industry structure favors skill group $\mathrm{k}$ in country $\mathrm{j}$ relative to the U.S., using U.S. weights.

Supply indexes $\Delta S_{\mathbf{k}}$ are computed as follows:

$$
\Delta S_{\mathbf{k}}=\ln E_{k j}-\ln E_{k u}
$$


where $E_{k j}$ and $E_{k u}$ are respectively, the share of country $j$ 's and the U.S.'s total labor input consisting of skill group $k$, using the U.S. cutoffs for skill groups. Thus, the supply indexes compare the relative representation of each slill group in country $j$ 's labor force, using the U.S. shares as the norm.

We may then compute net supply as:

$$
\Delta N S_{\mathbf{k}}=\Delta S_{\mathbf{k}}-\ln \left(1+\Delta D_{\mathbf{k}}\right)
$$

where $\Delta S_{k}$ and $\Delta D_{k}$ are defined in equations (11) and (12) above. (Recall that all magnitudes are in log points and have been normalized relative to the U.S.) As Katz and Murphy (1992) show using a simple equilibrium model, differences across countries in relative wages for each skill group will be negatively related to differences in net supply, $\Delta \mathrm{NS} \mathbf{k}$. Intuitively, the larger the supply of skill group $k$ relative to demand in country $j$ compared to the U.S., the worse skill group $\mathbf{k}$ will fare in country $\mathrm{j}$ compared to the U.S.

Table 9 presents results for the relative demand indexes by skill group. The actual entries are of the form $\ln \left(1+\Delta D_{k}\right)$ and are approximate percentage effects. The occupationindustry categories include six industries crossed with three occupation groups. ${ }^{28}$ Labor input is measured in hours in Panel $A$ and in eamings in Panel B. 29

The results in Table 9 indicate that demand tends to favor low and middle skill workers in other countries relative to the U.S., particularly when labor input is measured in eamings. In addition, when the eamings measure is used, the demand index for the low-skill group is a

28 The industries are : 1) agriculture; 2) mining, manufacturing and construction; 3) transportation, communication and public utilities; 4) trade; 5) finance, insurance, real estate and services; and 6) government. The occupations are 1) managers and professionals; 2) clerical and sales workers; and 3) craftsworkers, operatives, laborers and service workers.

29 For the purposes of constructing the demand and supply indexes, the self-employed are included in all countries. For the 1984 Sweden-U.S. comparison, part-time workers are included (in addition to full-time workers and the self employed) in measuring the labor input. 
bit (0.044 log points) larger, on average, than for the middle-skill group which might be consistent with a differential in favor of low-skill workers in other countries relative to the U.S. In contrast, demand appears less favorable to high-skill workers in other countries relative to the U.S., and this is not consistent with a differential between high-and middle-skill workers which tends to be the same or larger in other countries than in the U.S. Of course to fully evaluate the consequences of these patterns for relative wages, we need also to take into account relative supply.

Table 10 presents the supply indexes with the labor input measured in hours (Panel A) or in eamings (Panel B). The results indicate that while demand effects may be partially consistent with the observed wage gaps, supply effects are not. Using both measures hours and eamings), other countries have much greater shares of their labor input in low-skill labor and much smaller shares in high-skill labor. If relative supply were the entire explanation, then the middle vs. low skill pay gap should be smaller in the U.S. as should the high vs. middle skill pay gap. These indexes are not consistent with the wage differential findings in Table 8.

Relative demand and supply are considered together in Table 11 which shows the net supply indexes. Again, Panel A gives the results when labor input is measured in hours and Panel B gives the results using eamings. Table 11 clearly shows that the supply effects swamp the demand effects for low skill workers. Using both measures, net supply is positive for this group, on average, and within each country. While net supply is also positive, on average, for the middle-skill group, the average net supply figure for the low-skill group exceeds that for the middle-skill group for both the hours measure $(0.331 \mathrm{vs.} 0.095)$ and the earnings measure ( 0.490 vs. 0.146$).{ }^{30}$ Thus, the supply and demand analysis suggests that low skill workers

30 This is also the case in nine out of a possible eleven pair-wise (U.S. vs. country j) comparisons for both the hours and eamings measures. 
should in general fare worse relative to the middle in other countries than they do in the U.S. and cannot explain the smaller low-middle skill differentials that prevail in these countries.

In contrast to the pattern for the low skill group, the net supply effects for the high skill group are consistently negative. Further, they are, on average, quite large in absolute value (i.e., -0.785 using the hours measure and -0.710 using the eamings measure). While in two cases (Italy and Sweden 1984) net supply is also negative for middle-skill workers (using both measures), in none of the four possible cases is the net supply figure for the high-skill group larger than the net supply figure for the middle-skill group. Thus, supply and demand analysis would predict differentials in favor of high-skill workers in other countries relative to the U.S. While this may be consistent with the findings from Panel B of Table 8 that the U.S. differential is moderately (.034) smaller than the non-U.S. average, when we consider the high $(67-100)$ vs. low (0-33) wage differential, the results are inconsistent with the predictions of supply and demand analysis in virtually every case. Table 11 indicates that high-skill workers are considerably scarcer relative to low-skill workers in other countries relative to the U.S., yet Table 8 shows that with one exception (Switzerland), they earn more relative to low-skill workers in the U.S. than elsewhere.

Thus, differences in relative supplies and demands for skill in other countries compared to the U.S. do not appear to be broadly consistent with the observed pattern of relative wages by skill in other countries compared to the U.S. In particular, they do not explain the most striking difference between the U.S. and the other countries, namely their greater wage compression at the bottom relative to the top or the middle. Having said that, we must note some important qualifications. First, since relative wages for low skill workers are higher in all countries than in the U.S. and we use an employment-based measure of industry demand, we may have understated the demand for low skill workers that would occur at constant wages relative to the U.S. Similar reasoning implies that our supply estimates may have been overstated. Thus, we may have overestimated net supply at constant relative prices. Second, 
our demand index does not include any differences across countries in within industryoccupation demands for skill. It is unclear what effect this might have on our results.

Third, we have implicitly assumed a separability in production between other factors and the three skill groups. However, other factors such as women's labor may not be equally substitutable for male labor of different skill levels. Topel (1992), for example, has suggested that women's labor is more substitutable on average for low skill than for high or medium skill men. In our data, women's work hours account for a larger share of total hours worked in the U.S. (about 44\%) than in the other countries (36\%, on average). Topel's (1992) findings suggest that the relatively poor showing of low skill men in the U.S. could be due to its high female labor supply. While this phenomenon may explain a portion of our results, we believe that it is not the whole story. In particular, as shown in the next subsection, female labor supply differences across countries are much less closely related to differences in male wage inequality than are differences in wage-setting institutions.

Finally, we note that our findings may reflect an interplay of institutions and market forces. That is, given wage-setting institutions, it is possible that the wage gap between middle-and low-skill workers in other countries relative to the U.S. is larger than it would have been under more favorable net supply conditions for low-skill workers. Similarly, the high vs. middle skill differential in other countries might well have been more compressed relative to the U.S. had net supply conditions for high skill workers been less favorable. Even if this is the case, however, it does not negate the strength of the institutional forces. Indeed, the finding that the most striking difference between the U.S. distribution and that in the other industrialized countries in our sample--the greater compression at the bottom of the wage distribution-occurs in the face of supply and demand forces which would have produced the opposite result is powerful evidence in favor of the importance of wage setting institutions.

\section{E. The Effects of Institutions: Toward a General Test}

The evidence so far has suggested that the relatively decentralized wage-setting system in the United States is responsible for at least some of this country's higher wage dispersion 
and greater spread at the bottom of the distribution compared to the OECD countries in our sample. While our sample is relatively small $(10)$, it is still possible to investigate whether this relationship between centralization and the wage distribution holds generally, i.e. beyond the individual U.S. -other country comparisons which we have made up to this point. Performing such a test requires one to operationalize the concept of centralization in wage setting. Several authors have produced rankings of countries with respect to their extent of centralization, including Blyth (1979), Bruno and Sachs (1985), Calmfors and Driffill (1988), Cameron (1984), and Schmitter (1981). These rankings take into account the degree of coordination within and between labor and management organizations, the level at which bargaining takes place, and the power of central bodies to conduct wage negotiations (Calmfors and Driffill, 1988). We use as a measure of centralization the unweighted average of these rankings (which are shown individually in Calmfors and Driffill, 1988, p. 18), correcting for differences across authors in the number of countries ranked.

Based on this average ranking, Austria, with a ranking of 1.493 out of 17 countries, had the most centralized wage-setting system among the countries in our sample; while the U.S., with a ranking of 15.191 out of 17 , not surprisingly, had the least. ${ }^{31}$ While Hungary as a Communist country in the 1980s was not included in the rankings, we assigned it the highest level of centralization since the government set wages there. The results were qualitatively similar when Hungary was excluded from the analyses.

We then used this (inverse) measure of centralization (DECENT) as an explanatory variable in two kinds of analyses. First, we ran regressions with the following dependent variables: i) the country's standard deviation of YFULL (i.e., the log of hours-corrected earnings, as shown in Table 1); ii-iii) the 50-10 and 90-50 differentials in YFULL (Table 1); iv-v) the 50-10 and 90-50 prices effects (i.e., YFULL net of personal characteristics) for the

31 The degree of centralization for the other countries in our sample was: West Germany 6.943; Britain 12.632; Switzerland 10.904; Sweden 2.736; Norway 2.536; Australia 10.766; and Italy 14.325. 
country in question relative to the U.S. with the full specification (Table 3B). ${ }^{32}$ In addition, in light of Topel's (1992) findings on the impact of female labor supply on male wage inequality, we included the log of the share of total hours worked by women (LNFEM) as an explanatory variable in some specifications. ${ }^{33}$

The second kind of aggregate cross-country analysis involved estimating the determinants of the middle-low and high-middle skill group log wage differentials, as shown in Table 8 (absolute skill groups-i.e., U.S. cutoffs for SKILL-were used here). Explanatory variables in this case included DECENT, the log of relative female labor supply measured in hours, and relative net supply. For example, in the analysis of the middle-low skill group wage differential, the net supply of middle skill relative to the low skill group was included as a right-hand variable. Since the net supply measures are defined relative to the U.S. (Table 11), we define the wage differentials and female labor supply relative to the U.S. as well. ${ }^{34}$ Tables 12 and 13 contain our results. The major findings are for DECENT and are striking. First, decentralization of wage setting is found to be positively associated with the standard deviation of log wages (Table 12). This effect is 2.6-2.9 times its standard error and holds whether or not female labor supply is included and whether or not the effects of the distribution of male personal characteristics have been removed. At the mean value of DECENT, the coefficients imply an elasticity of the standard deviation of wages of 0.10-0.12.

Second, as was the case in the U.S.-country $\mathrm{j}$ comparisons of Table 1, wage compression at the bottom of the distribution appears responsible for the association between centralization and the overall log wage variance. For example, in Table 12, decentralized

32 In these analyses, the two observations on Norway were averaged using sample size as weights. Sweden 1984 was excluded since the wage variable in that analysis was defined as log of actual hourly earnings, unlike the rest of the sample.

33 The results were unchanged when female labor input was measured as the share of all earnings accounted for by women.

34 The U.S. was included and given zeroes for relative wages and relative female labor supply. DECENT is, up to a constant, already defined relative to the U.S. 
wage-setting has a positive association with the 50-10 log wage differential. The effect is robust with respect to controlling for the distribution of male personal characteristics and the inclusion of relative female labor supply. It is 2.2-3.8 times its standard error and implies an elasticity of the 50-10 wage ratio of $0.12-0.25$. Similar findings for compression at the bottom of the distribution are obtained in Table 13 which examines wage differentials between skill groups. Specifically, decentralization of wage-setting has a positive association with the middle-low skill log wage gap whether or not we control for relative net supply of these two groups and relative female labor supply. The DECENT effects for the middle-low differential in Table 13 are 2.0-2.5 times their standard errors and correspond to elasticities of 0.09-0.10.

In contrast to the strong positive association between centralization and wage compression at the bottom of the distribution, DECENT has very weak effects on compression at the top. In Tables 12 and 13, decentralization of pay-setting has small positive effects on the 90-50 or high-middle skill group wage gap which are in every case but two smaller than their standard errors.

In contrast to the findings for DECENT on wage compression at the bottom of the distribution, the results for female labor supply are mixed and generally not precisely estimated. In Table 12, greater female labor supply is associated with a larger 50-10 male wage differential (as predicted by Topel's (1992) results), but the effect is smaller than its standard error in three of four cases, and is not significant in the specification where we control for measured male personal characteristics. In Table 13, female labor supply has the "wrong" sign for the middle-low wage gap (i.e. it is negatively associated with the gap) and is 0.3 times its standard error. Finally, the effects of female labor supply on overall male wage variance (Table 12) and wage compression between the top and the middle of the distribution, as shown in Tables 12 and 13, charge sign depending on specification and are in all cases but one smaller than their standard errors.

The effects of net supply shown in Table 13 are also mixed. On the one hand, net supply has the "wrong" sign for the middle-low wage gap-it is positively associated with this

DNTAGE2.DOC 222294 3:31 PM 
gap; however, it is smaller than its standard error. On the other hand, net supply is negatively associated with the high-middle pay gap, as predicted and suggested by Tables 8 and 11, and is 1.9 times its standard error.

The results of Tables 12 and 13 suggest that wage centralization leads to less wage inequality generally and that it has a particularly strong effect in bringing up the bottom of the wage distribution. Admittedly, our sample of countries is extremely small-only 10; and the causality between the wage distribution and wage setting institutions, as well as our measures of female labor supply and net male labor supply, can run in both directions. However, these results in conjunction with the individual U.S.-other country comparisons lend plausibility to the idea that institutions are important.

\section{rV. Conclusions}

In this paper, we have compared male wage inequality in the U.S. and nine other industrialized countries primarily in the middle to late 1980 s. Consistent with previous work, the results indicate that overall wage inequality is much greater in the U.S. than elsewhere. Interestingly, however, when we disaggregate the measure of inequality to examine various parts of the wage distribution, we find that the distribution in other countries is much more compressed at the bottom relative to the U.S. than at the top. Thus, while the 50-10 differential is considerably larger in the U.S. than elsewhere, the U.S. $90-50$ differential is quite similar to that in other countries.

We then evaluated several possible explanations for these patterns of inequality. First, differences in the distribution of measured characteristics across countries were found to be responsible for some but not all of the international differences in the wage distribution. If the U.S. had other countries' distribution of measured characteristics, its overall wage variation would remain much higher than elsewhere. Moreover, while the gap between the middle and bottom portions of the U.S. wage distribution would be reduced, the high-middle gap would be increased. Most importantly, the wage distribution in other countries would still be more 
compressed at the bottom than at the top relative to the U.S. These results suggests that U.S. labor market prices contribute to our observed findings.

Second, we noted that, unlike the U.S., most of the other countries have very centralized systems of collective bargaining and many have provisions to extend the terms of union contracts to nonunion workers. Voluntary emulation by nonunion firms of the union wage structure due to threat effects is also expected to be greater in these other countries given the larger size of their union sectors. Consistent with these observations, we found a larger variance of wages and less wage compression at the bottom within both the U.S. union and nonunion sectors compared to other countries. Indeed, the larger variance of overall wages in the U.S. is primarily due to the higher variance that prevails here within each of these sectors. Moreover, controlling for the distribution of measured characteristics, both of these salient features of the U.S. distribution-a higher wage variance and a lesser compression at the bottom--are more pronounced in the nonunion than in the union sector. This result suggests that contract extension and other mechanisms which extend union-determined wages to the nonunion sector have a larger effect on their wage structures relative to the U.S. than do their more centralized wage-setting institutions within the union sector.

Third, we examined indexes of relative supplies and demands across countries to see whether market forces could provide an alternative explanation for the observed patterns, particularly for the high relative wages of low skilled workers in other countries. Demand effects were found to be weakly consistent with the greater non-U.S. compression at the bottom, but relative supply was inconsistent with this pattern. Taking both supply and demand into account suggested that low-skill workers should fare worse relative to the middle in other countries than they do in the U.S. and cannot explain the smaller low-middle skill differentials that prevail in these countries. Thus, market forces, as best as we could measure them, do not appear to be consistent with the observed pattern of relative wages by skill in other countries compared to the U.S. 
Finally, we present evidence that wage centralization, as commonly measured by comparative industrial relations researchers, is negatively associated with wage dispersion, the 50-10 differential in the log of wages, and the pay gap between middle and low skill workers. Further, this compression at the bottom occurs even when we control for the distribution of personal characteristics, relative female labor supply, and relative male labor supply net of demand differences.

Our findings provide strong evidence for the importance of labor market institutions in explaining intemational differences in the levels of wage inequality. To the extent that institutions are important, we would expect adverse impacts on employment and productivity due to resource allocation effects. To some degree, labor market policies such as government employment or training programs and relocation subsidies can compensate for such effects. One interpretation of government labor market policy in many OECD countries, then, is that wage-leveling policies are encouraged by the government on the one hand to achieve a desired level of wage inequality. The greater compression at the bottom, in particular, suggests that these other countries use the labor market to a greater extent than in the U.S. to provide a "safety net" for low wage workers. On the other hand, the more activist government policies regarding employment, training and relocation often found in these countries (see, e.g., Edin and Holmlund, forthcoming) may be seen in part as corrective measures for the adverse . employment and allocation effects of the wage distribution policies. 


\section{References}

Blackbum, McKinley L. and David E. Bloom, "Changes in the Structure of Family Income Inequality in the U.S. and Other Industrialized Nations During the 1980s, " (June 1991).

Blanchflower, David and Richard Freeman, "Unionism in the U.S. and Other Advanced O.E.C.D. Countries," Industrial Relations 31 (Winter 1992): 56-79. Blank, Rebecca, "Why Were Poverty Rates So High in the 1980s?" NBER Working Paper
3878, October I991.

Blau, Francine D., Equal Pay in the Office (Lexington, Mass: D.C. Heath, 1977).

Blau, Francine D. and Lawrence M. Kahn, "The Gender Eamings Gap: Learning from Intemational Comparisons," American Economic Review 82 (May 1992): 533-538.

Blau, Francine D. and Lawrence M. Kahn, "The Gender Eamings Gap: Some International Evidence," in Richard Freeman and Lawrence Katz, eds., Differences and Changes in Wage Structures, (Chicago, IL: University of Chicago Press, forthcoming).

Blau, Francine D, and Lawrence M. Kahn, "The Impact of Wage Structure on Trends in U.S. Gender Wage Differentials: 1975-87," paper presented at the NBER Labor Studies Conference, Cambridge, MA., March 1993.

Blyth, C.A., "The Interaction between Collective Bargaining and Govemment Policies in Selected Member Countries," in OECD, Collective Bargaining and Government Policies (Paris: OECD, 1987), pp. 59-93.

Bound, John, and George Johnson, "Changes in the Structure of Wages in the 1980's: An Evaluation of Altemative Explanations," American Economic Review 82 (June 1992): 371-392.

Bruno, M. and J. Sachs, The Economics of Worldwide Stagflation (Oxford: Basil Blackwell, 1985).

Calmfors, Lars and John Driffill, "Centralization of Wage Bargaining," Economic Policy 6 (April 1988): 14-61.

Cameron, D. R., "Social Democracy, Corporatism, Labour Quiescence and the Representation of Economic Interest in Advanced Capitalist Society," in J. H. Goldthorpe, ed., Order and Conflict in Contemporary Capitalism (Oxford: Clarendon, 1984), pp. 143-178.

Chamberlain, Gary, "Quantile Regression, Censoring, and the Structure of Wages, " mimeo, Harvard University, June 1991.

Cutler David M. and Lawrence F. Katz, "Macroeconomic Performance and the Disadvantaged," Brookings Papers on Economic Acriviry, 1991, pp. 1-74.

Davis, Steven J., "Cross-Country Patterns of Change in Relative Wages," NBER Working Paper No. 4085, June 1992. 
Davis, Steven J. and John Haltiwanger, "Wage Dispersion between and within U.S. Manufacturing Plants," Brookings Papers on Economic Activity: Microeconomics, 1991, pp. 115-180.

Deaton, D.R. and P.B. Beaumont, "The Determinants of Bargaining Structure: Some Large Scale Survey Evidence for Britain," British Joumal of Industrial Relations 18 (July 1980): $202-216$.

Edin, Per-Anders and Bertil Holmlund, "The Swedish Wage Structure: The Rise and Fall of Solidarity Wage Policy," in Richard Freeman and Lawrence Katz, eds., Differences and Changes in Wage Structures, (Chicago, IL: University of Chicago Press, forthcoming).

Ehrenberg, Ronald G. and Robert S. Smith, Modern Labor Economics, 5th edition (New York: Harper Collins, 1994).

Erickson, Chris and Andrea Ichino, "Wage Differentials in Italy: Market Forces and Institutions," in Richard Freeman and Lawrence Katz, eds., Differences and Changes in Wage Structures, (Chicago, IL: University of Chicago Press, forthcoming).

European Industrial Relations Review, (ElRR), "New Industrial Relations Talks Continue," No. 192 (January 1990): 7.

European Industrial Relations Review, (ElRR), "Italy," No. 223 (August 1992): 9-10.

European Industrial Relations Review, (EIRR), "Minimum Pay in 18 Countries," No. 225 (October 1992): 14-21.

European Industrial Relations Review, (EIRR), "Minimum Pay Setting: Germany," No. 226 (November 1992): 14-16.

Freeman, Richard B., "Unionism and the Dispersion of Wages," Industrial and Labor Relations Review 34 (October 1980): 3-23.

Freeman, Richard B., "Union Wage Practices and Wage Dispersion Within Establishments," Industrial and Labor Relations Review 36 (October 1982): 3-21.

Gottschalk, Peter and Mary Joyce, "Changes in Eamings Inequality: An International Perspective," mimeo, Boston College, 1992.

Groshen, Erica L., "The Structure of the Female/Male Wage Differential: Is it Who Your Are, What You Do, or Where You Work?" Joumal of Human Resources 26 (Summer 1991): 457-72.

Hendricks, Wallace E. and Lawrence M. Kahn, "The Determinants of Bargaining Structure in U.S. Manufacturing Industries," Industrial and Labor Relations Review 35 (January 1982): 181-195.

Hendricks, Wallace E. and Lawrence M. Kahn, Wage Indexarion in the United States: Cola or Uncola? (Cambridge, Mass.: Ballinger, 1985).

ILO, Yearbook of Labour Staristics, 1991 (Geneva: ILO). 
Juhn, Chinhui, Kevin M. Murphy, and Brooks Pierce, "Accounting for the Slowdown in Black-White Wage Convergence," in M. Kosters, ed., Workers and Their Wages (Washington, D.C.: AEI Press, 1991), pp. 107-143.

Juhn, Chinhui, Kevin M. Murphy, and Brooks Pierce, "Wage Inequality and the Rise in Retums to Skill," Journal of Political Economy, 101 (June 1993): 410-442.

Kahn, Lawrence M. and Michael Curme, "Unions and Nonunion Wage Dispersion," The Review of Economics and Statistics 69 (November 1987): 600-607.

Katz, Harry C., "The Decentralization of Collective Bargaining: A Literature Review and Comparative Analysis," Industrial and Labor Relations Review 47 (October 1993): 322.

Katz, Lawrence F., Gary W. Loveman and David Blanchflower, "A Comparison of Changes in the Structure of Wages in Four OECD Countries," in Richard Freeman and Lawrence Katz, eds., Differences and Changes in Wage Structures, (Chicago, IL: University of Chicago Press, forthcoming).

Katz, Lawrence F. and Kevin M. Murphy, "Changes in Relative Wages, 1963-87: Supply and Demand Factors," Quarterly Joumal of Economics, 107 (February 1992): 35-78.

Kennedy, Thomas, European Labor Relations (Lexington, Mass.: D.C. Heath, 1982).

Killingsworth, Mark, The Economics of Comparable Worth (Kalamazoo, Mich.: W.E. Upjohn Institute for Employment Research, 1990)

Koenker, Roger and Gilbert Bassett, "Regression Quantiles," Econometrica 46 (January 1978): 33-50.

Krueger, Alan and Lawrence Summers, "Efficiency Wages and the Inter-Industry Wage Structure," Econometrica 56 (March 1988): 259-293.

LaLonde, Robert J. and Robert H. Topel, "The Assimilation of Immigrants in the U.S. Labor Market," in G. Borjas and R. Freeman, eds., Immigration and the Work Force (Chicago:, Ill.: University of Chicago Press, 1992): 67-92.

Leion, Anders, "Sweden," in B.C. Roberts, ed., Industrial Relations in Europe (London: Croom Helm, 1985), pp. 204-221.

Rezler, Julius, "The Industrial Relations System in Hungary After the Economic Reform, " in Universite de Strasbourg, Annaire de L'URSS et des Pays Socialistes Europeens 19723, pp. 385-405.

Rosenfeld, Rachel and Ame Kalleberg, "A Cross-national Comparison of the Gender Gap in Income," American Joumal of Sociology 96 (July 1990): 69-106.

Schmitter, P.C., "Interest Intermediation and Regime Governability in Contemporary Western Europe and North America," in S.D. Berger, ed., Organizing Interests in Western Europe (Cambridge, Mass.: Cambrịge University Press, 1981), pp. 287-327.

Thorsrud, Einar, "Norway," in B.C. Roberts, ed., Industrial Relations in Europe (London: Croom Heim, 1985), pp. 180-203. 
Tomandl, Theodor and Karl Fuerboeck, Sociol Partnership (Ithaca, N.Y.: ILR Press, 1986).

Topel, Robert H., "Wage Inequality and Regional Labor Market Performance in the United States," mimeo, University of Chicago, June 1992.

Treu, T., "Italy, " Bulletin of Comparative Labour Relations 19 (1990): 227-250.

U.S. Bureau of Labor Statistics, Handbook of Labor Statistics, 1985 (Washington, D.C.: U.S. Government Printing Office).

U.S. Department of Commerce, Staristical Abstract of the United States 1992 (Washington, D.C.: U.S. Government Printing Office, 1992).

U.S. Department of Labor, Foreign Labor Trends: Hungary 1991-2 (Washington, D.C.: U.S. Government Printing Office, 1992).

Wrong, Gale, "Switzerland," Bulletin of Comparative Labour Relations 16 (1987): 183-201. 


\section{Appendix}

Variable Definitions, Means and Earnings Regression Results by Country

Definitions of the explanatory variables are given in Table A-1. The earnings definitions for each country are listed below:

Austria: Net Monthly Income from Employment

Germany and Switzerland: Net Income per Month after taxes and social insurance

Italy: Annual labor income

Britain: Total annual eamings before taxes

USA: Previous year's eamings from occupation before taxes

Hungary: Monthly eamings

Sweden: Income (from all sources) in previous year

Norway: Annual income from all jobs.

Australia: Annual eamings from all jobs. 
Table A-1

Definitions of Explanatory Variables

EDUC $=$ years of schooling completed

PEXP $=$ age - EDUC -6

$P E X P S Q=P E X P$ squared

EXP $=$ actual experience (PSID and HUS only)

EXPSQ = EXP squared (PSID and HUS only)

MAR $=1$ if married spouse present and 0 otherwise

UNION = dummy variable for union membership

Occupation dummy variables:

PROF = professional and technical workers (the omitted category)

MGR = managers, except farm

CLER = clerical workers

SALES $=$ sales workers

CRAFT $=$ craft workers

OPER = operatives

$\mathrm{LAB}=$ laborers, except farm

SERVWK = service workers

FARMMGR $=$ farm managers

FARMLAB = farm laborers

Industry dummy variables:

AG $=$ agriculture, forestry and fisheries

MINCON $=$ mining and construction

MANDUR = durable goods manufacturing

MANNON = nondurable goods manufacturing

TRANS $=$ transportation, communications and utilities

WTRADE $=$ wholesale trade

RTRADE = retail trade

FIRE = finance, insurance and real estate

SERVS $=$ services

GOVT $=$ government (the omitted category).

Industry dummy variables for Hungary:

AG (see above)

MINMAN $=$ mining and manufacturing

CONST $=$ construction

TRANS (see above)

TRADE = wholesale and retail trade

SERVS = services, finance insurance and real estate

GOVT (see above), the omitted category

Occupation dummy variables for Australia:

MGR = managers and farm managers

CLER, CRAFT, and OPER (see above)

$\mathrm{LAB}=$ laborers and farm laborers

SALESW = sales and service workers

PROF (see above), the omitted category 
Table A-1, cont'd

Definitions of Explanatory Variables

Industry dummy variables for Australia:

AG, TRANS, MINCON (see above)

MANUF = manufacturing

TRADE = wholesale and retail trade

FISERV = finance, insurance, real estate and services

GOVT (see above), the omitted category

Occupation dummy variables for Italy:

BLUE = blue collar

WHITELOW = lower level white collar

WHTEHI = higher level white collar, the omitted category

Industry dummy variables for Italy:

AG, TRANS, TRADE (see above)

IND = Mining, Construction and Manufacturing

FIRE, GOVT (see above)

SERVS (see above), the omitted category 


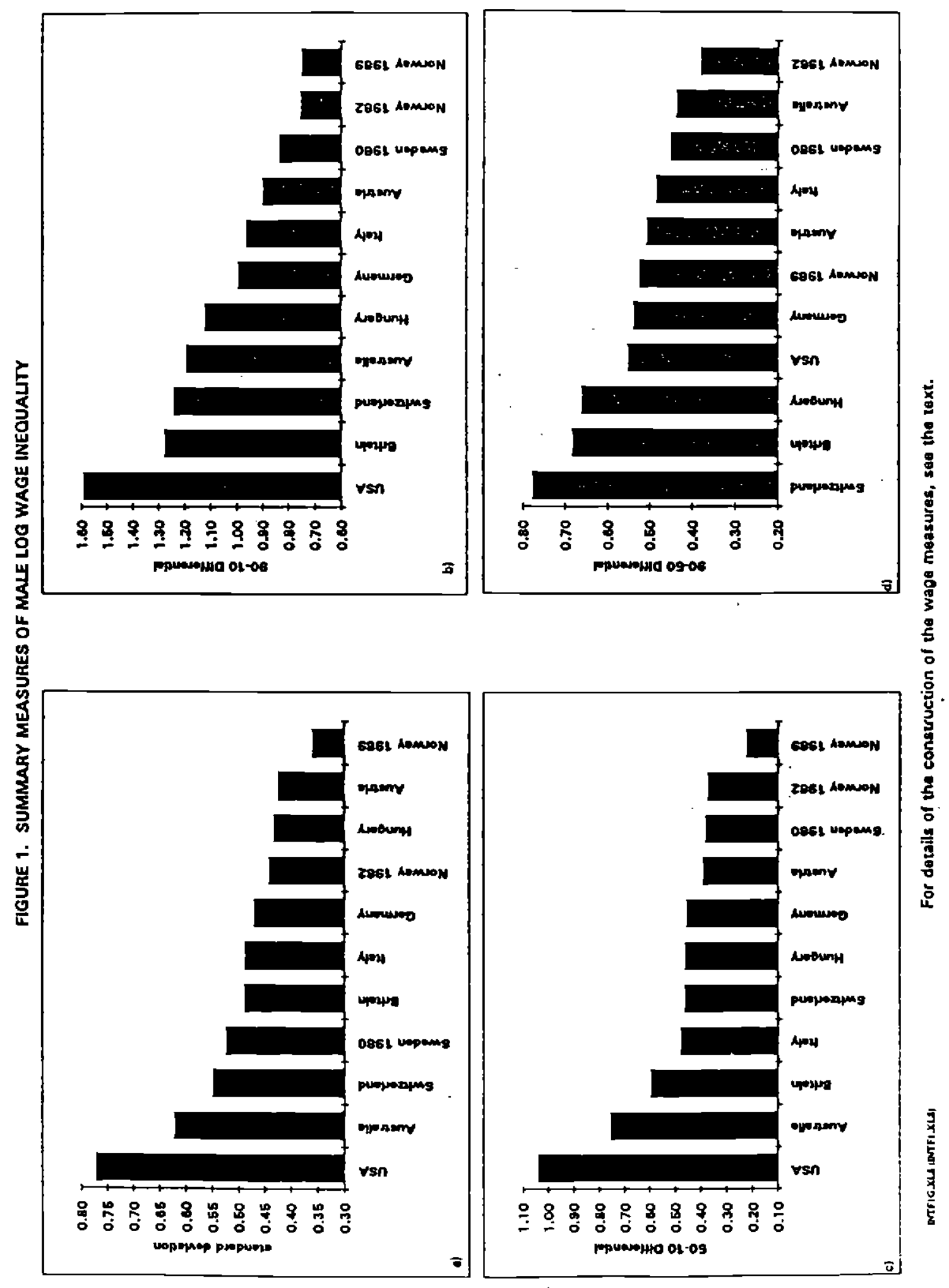


TABLE 1

SUMMARY MEASURES DF WAGE INEQUAUTY

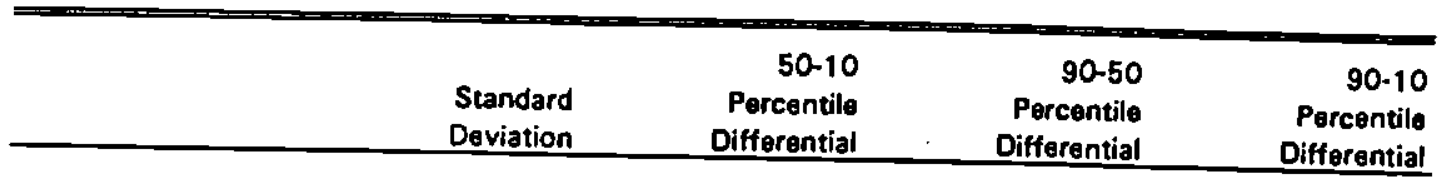

A. Log Hours-Correctod Earnings

\begin{tabular}{lllll} 
Germany & 0.470 & 0.456 & 0.539 & 0.995 \\
Britain & 0.489 & 0.594 & 0.683 & 1.277 \\
USA & 0.772 & 1.040 & 0.552 & 1.592 \\
Austria & 0.424 & 0.391 & 0.508 & 0.899 \\
Switzerland & 0.549 & 0.464 & 0.777 & 1.241 \\
Sweden 1980 & 0.523 & 0.382 & 0.452 & 0.834 \\
Norway 1982 & 0.441 & 0.372 & 0.382 & 0.754 \\
Australia & 0.622 & 0.755 & 0.439 & 1.194 \\
Hungary & 0.431 & 0.462 & 0.661 & 1.123 \\
Italy & 0.488 & 0.478 & 0.486 & 0.964 \\
Norway 1989 & 0.360 & 0.224 & 0.525 & 0.749 \\
Non-US Average & & & & \\
IUnweighted) & 0.480 & 0.458 & 0.545 & 1.003 \\
& & 8. Log Hourly Eamings & & \\
Sweden 1984 & 0.343 & 0.254 & 0.388 & 0.642 \\
USA 1984 & 0.543 & 0.772 & 0.546 & 1.318 \\
\hline
\end{tabular}


TABLE 2

DECOMPOSITION OF THE US-COUNTRY J DIFFERENCES

IN THE STANDARD DEVLATION DF LOG WAGES

\begin{tabular}{rrrr}
\hline US Std Dev & Measured & Wage & Wage \\
- Country j & Characteristics & Coefficients & $\begin{array}{r}\text { Equation } \\
\text { Std Dev }\end{array}$ \\
\hline
\end{tabular}

A. Human Capital Specification

\begin{tabular}{|c|c|c|c|c|}
\hline Germany & 0.301 & 0.008 & 0.020 & 0.274 \\
\hline Britain & 0.283 & 0.044 & 0.021 & 0.218 \\
\hline Austria & 0.348 & 0.006 & 0.062 & 0.279 \\
\hline Switzerland & 0.223 & 0.001 & 0.035 & 0.187 \\
\hline Sweden 1980 & 0.248 & 0.034 & 0.017 & 0.197 . \\
\hline Norway 1982 & 0.331 & 0.018 & 0.047 & 0.266 \\
\hline Australia & 0.150 & 0.014 & 0.036 & 0.100 \\
\hline Hungary & 0.340 & 0.038 & 0.078 & 0.224 \\
\hline Italy & 0.284 & -0.0004 & 0.048 & 0.236 \\
\hline Norway 1989 & 0.411 & 0.023 & 0.042 & 0.347 \\
\hline Swoden 1984 & 0.200 & -0.001 & 0.069 & 0.132 \\
\hline Non-US Average & 0.284 & 0.017 & 0.043 & 0.224 \\
\hline \multicolumn{5}{|c|}{ B. Full Specification } \\
\hline Germany & 0.301 & 0.021 & 0.032 & 0.248 \\
\hline Britain & 0.283 & 0.037 & 0.037 & 0.209 \\
\hline Austria & 0.348 & 0.008 & 0.075 & 0.265 \\
\hline Switzerland & 0.223 & -0.004 & 0.032 & 0.195 \\
\hline Sweden 1980 & 0.248 & 0.032 & 0.018 & 0.198 \\
\hline Norway 1982 & 0.331 & 0.014 & 0.071 & 0.246 \\
\hline Australia & 0.150 & 0.007 & 0.051 & 0.092 \\
\hline Hungary & 0.340 & 0.025 & 0.111 & 0.205 \\
\hline Italy & 0.284 & 0.020 & 0.037 & 0.227 \\
\hline Norway 1989 & 0.411 & 0.008 & 0.076 & 0.327 \\
\hline Swoden 1984 & 0.200 & 0.011 & 0.080 & 0.109 \\
\hline $\begin{array}{l}\text { Non-US Average } \\
\text { (Unwoighted) }\end{array}$ & 0.284 & 0.016 & 0.056 & 0.211 \\
\hline
\end{tabular}

INTT1.XLS 2/21/94 3:30 PM (allwoind,yls) 
TABLE 3

DECOMPOSITION OF THE US-COUNTRY J DIFFERENCES IN

THE 50-10 AND 90-50 DIFFERENTLALS IN LOG WAGES

A. Human Capital Specification

\begin{tabular}{rrrr}
\hline US Differential & Measured & Wage & Wage \\
- Country 1 & Characteristics & Coefficients & Equation \\
Differential & Effect & Effect & Residual Effect \\
\hline
\end{tabular}

Germany
Eritain
Austria
Switzerland
Sweden 1980
Norway 1982
Australia
Hungary
Jtaly
Norway 1989
Sweden 1984
Non-US Average
(Unweighted)

0.584

0.446

0.649

0.576

0.658

0.668

0.285

0.578

0.562

0.816

0.518

0.576

0.013

$-0.131$

0.044

$-0.225$

0.100

0.170

0.113

$-0.109$

0.066

0.027

0.158

Sweden 1984

50-10 Log Wage Differential

$\begin{array}{lrl}0.312 & -0.019 & 0.291 \\ 0.083 & 0.089 & 0.274 \\ 0.299 & -0.005 & 0.355 \\ 0.254 & 0.053 & 0.269 \\ 0.385 & 0.034 & 0.239 \\ 0.331 & -0.013 & 0.350 \\ 0.069 & 0.068 & 0.148 \\ 0.158 & 0.038 & 0.382 \\ 0.246 & 0.041 & 0.275 \\ 0.338 & -0.037 & 0.515 \\ 0.225 & 0.018 & 0.275\end{array}$

0.245

0.024

0.307

90-50 Log Wage Differential

$\begin{array}{lrl}-0.183 & 0.095 & 0.101 \\ -0.134 & -0.043 & 0.046 \\ -0.199 & 0.121 & 0.122 \\ -0.300 & 0.046 & 0.029 \\ -0.075 & 0.078 & 0.097 \\ -0.132 & 0.086 & 0.216 \\ -0.067 & 0.054 & 0.126 \\ -0.190 & 0.208 & -0.127 \\ -0.151 & 0.114 & 0.103 \\ -0.104 & 0.065 & 0.066 \\ -0.190 & 0.152 & 0.196\end{array}$

Non-US Average

(Unweighted)

0.021

$-0.157$

0.089

0.089 
TABLE 3 CONT'D

DECOMPDSTTION OF THE US-COUNTRY J DIFFERENCES IN

THE 50-10 AND 90-50 DIFFERENTLALS IN LOG WAGES

8. Full Specification

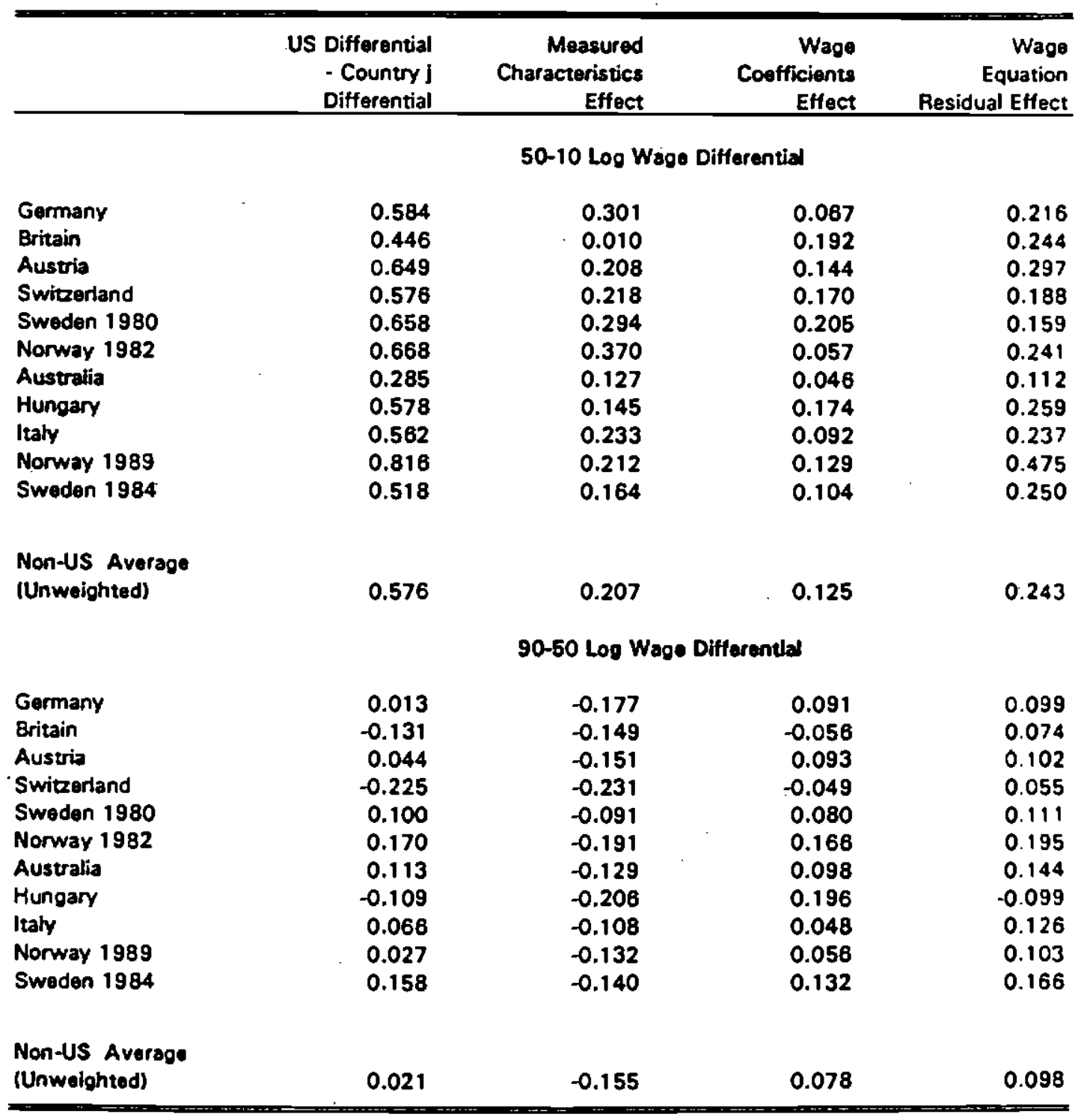

INT1 1.XLS 2/21/94 3:36 PM (allw6ind.xde) 


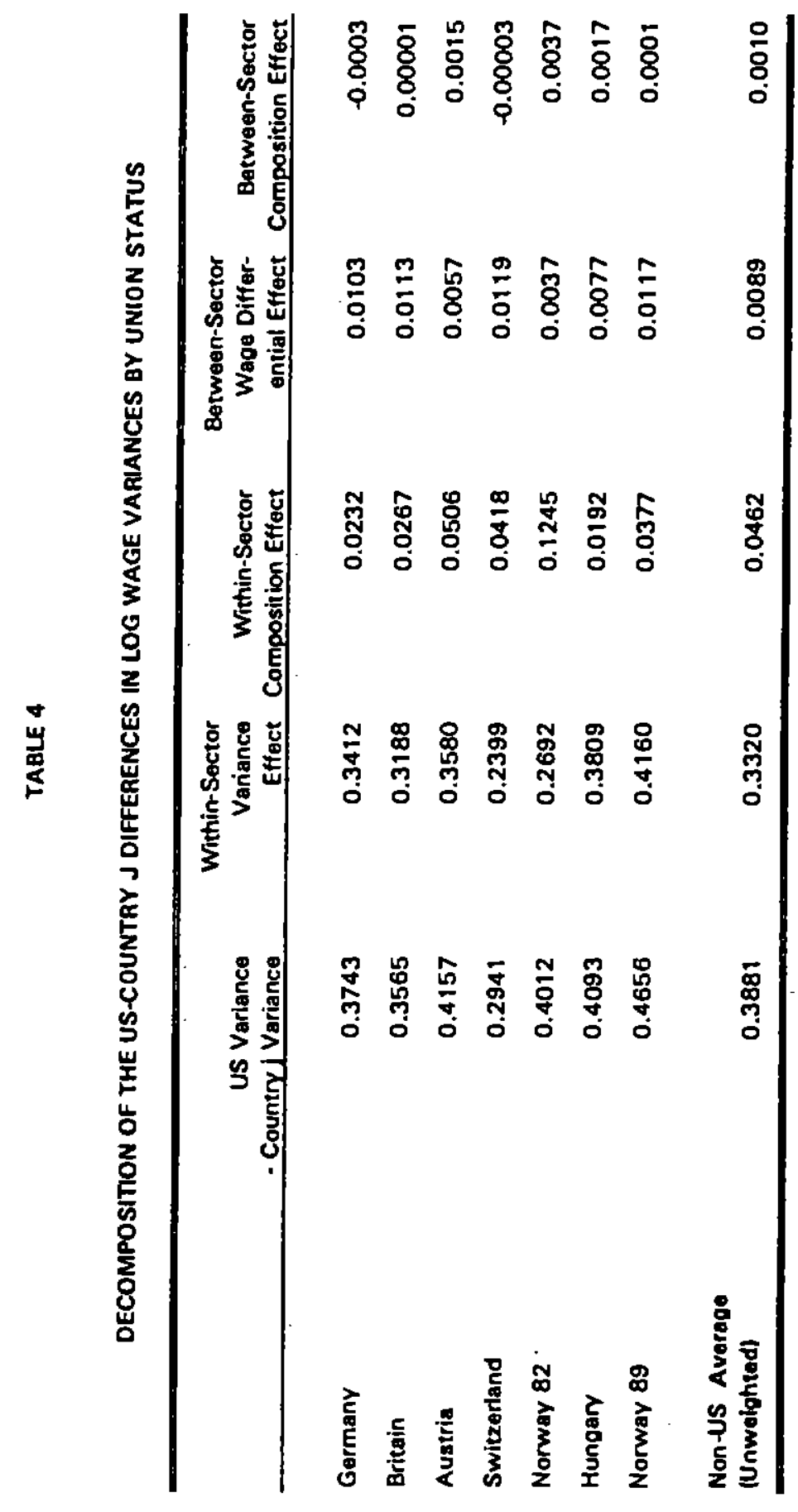

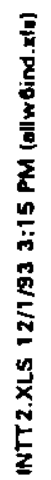


TABLE 5

SUMMARY MEASURES OF WAGE INEOUALITY BY UNION STATUS

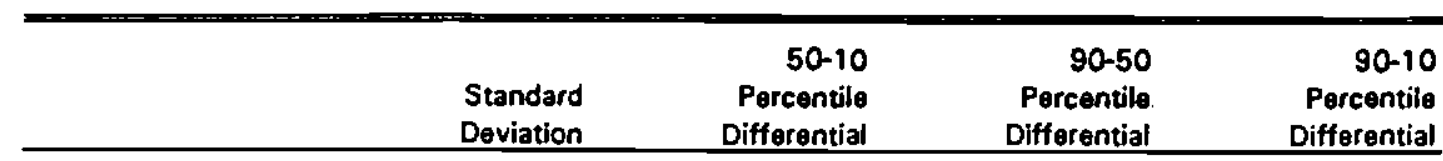

A. Union Workers

$\begin{array}{lllll}\text { Germany } & 0.361 & 0.362 & 0.508 & 0.870 \\ \text { Britain } & 0.436 & 0.510 & 0.532 & 1.042 \\ \text { USA } & 0.633 & 0.669 & 0.416 & 1.105 \\ \text { Austria } & 0.348 & 0.365 & 0.446 & 0.811 \\ \text { Switzerland } & 0.430 & 0.447 & 0.779 & 1.226 \\ \text { Norway 1982 } & 0.321 & 0.445 & 0.290 & 0.735 \\ \text { Hungary } & 0.410 & 0.511 & 0.606 & 1.117 \\ \text { Norway 1989 } & 0.309 & 0.185 & 0.506 & 0.691 \\ & & & & \\ \text { Non-US Averago } & 0.374 & 0.404 & 0.524 & 0.927 \\ \text { (Unweightod) } & & & \end{array}$

B. Nonunion Workers

\begin{tabular}{lllll} 
Gormany & 0.525 & 0.513 & 0.559 & 1.072 \\
Britain & 0.536 & 0.641 & 0.816 & 1.457 \\
USA & 0.799 & 1.082 & 0.622 & 1.704 \\
Austria & 0.506 & 0.459 & 0.579 & 1.038 \\
Switzertand & 0.625 & 0.479 & 0.781 & 1.260 \\
Norway 1982 & 0.614 & 0.626 & 0.575 & 1.201 \\
Hungary & 0.461 & 0.386 & 0.626 & 1.012 \\
Norway 1989 & 0.435 & 0.509 & 0.383 & 0.892 \\
& & & & \\
Non-US Avorage & 0.529 & 0.516 & 0.617 & 1.133 \\
(Unwelahtod) & & & & \\
\hline
\end{tabular}

INTT1.XLS 12/1/93 3:12 PM (allw Bind.xds] 


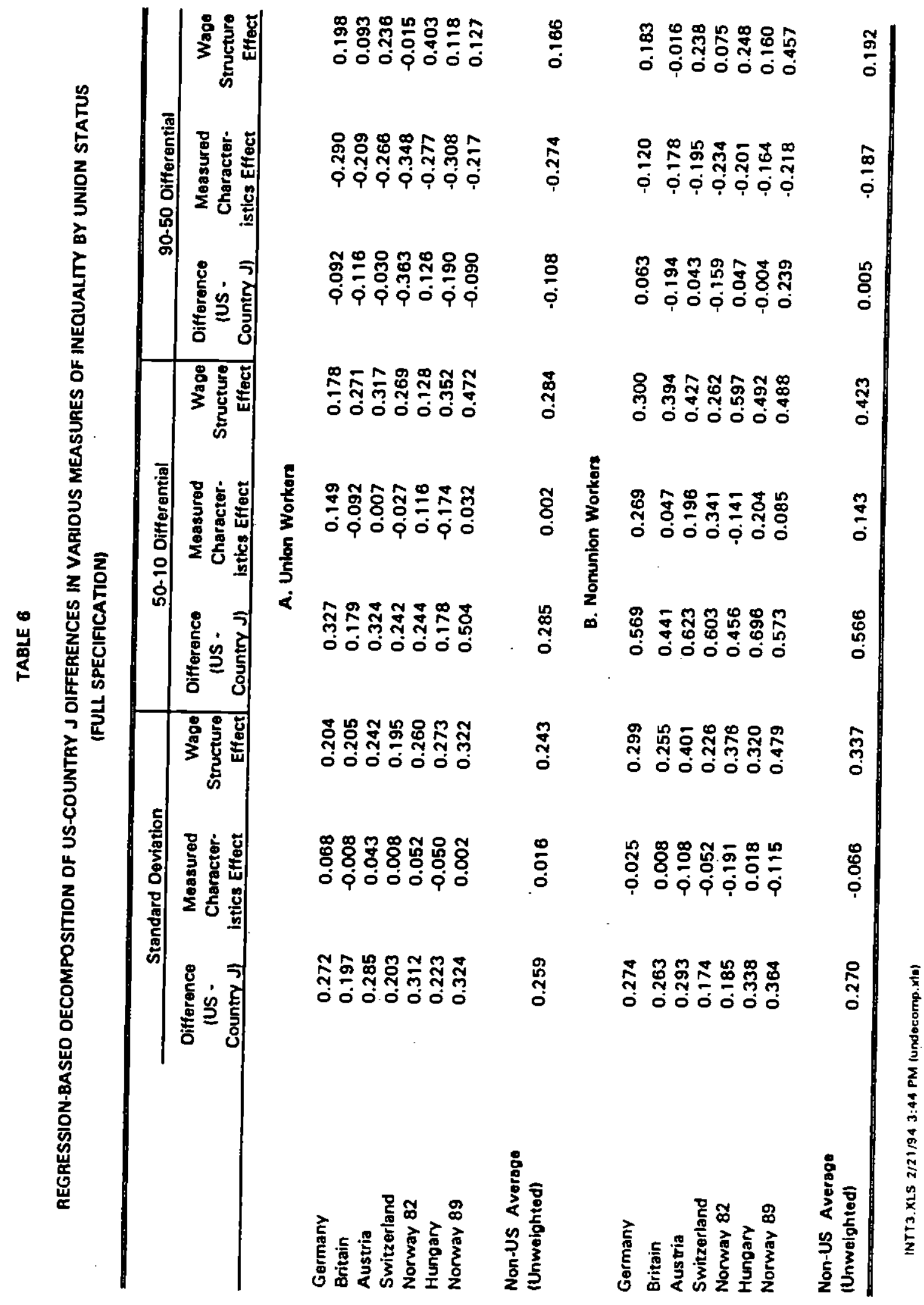




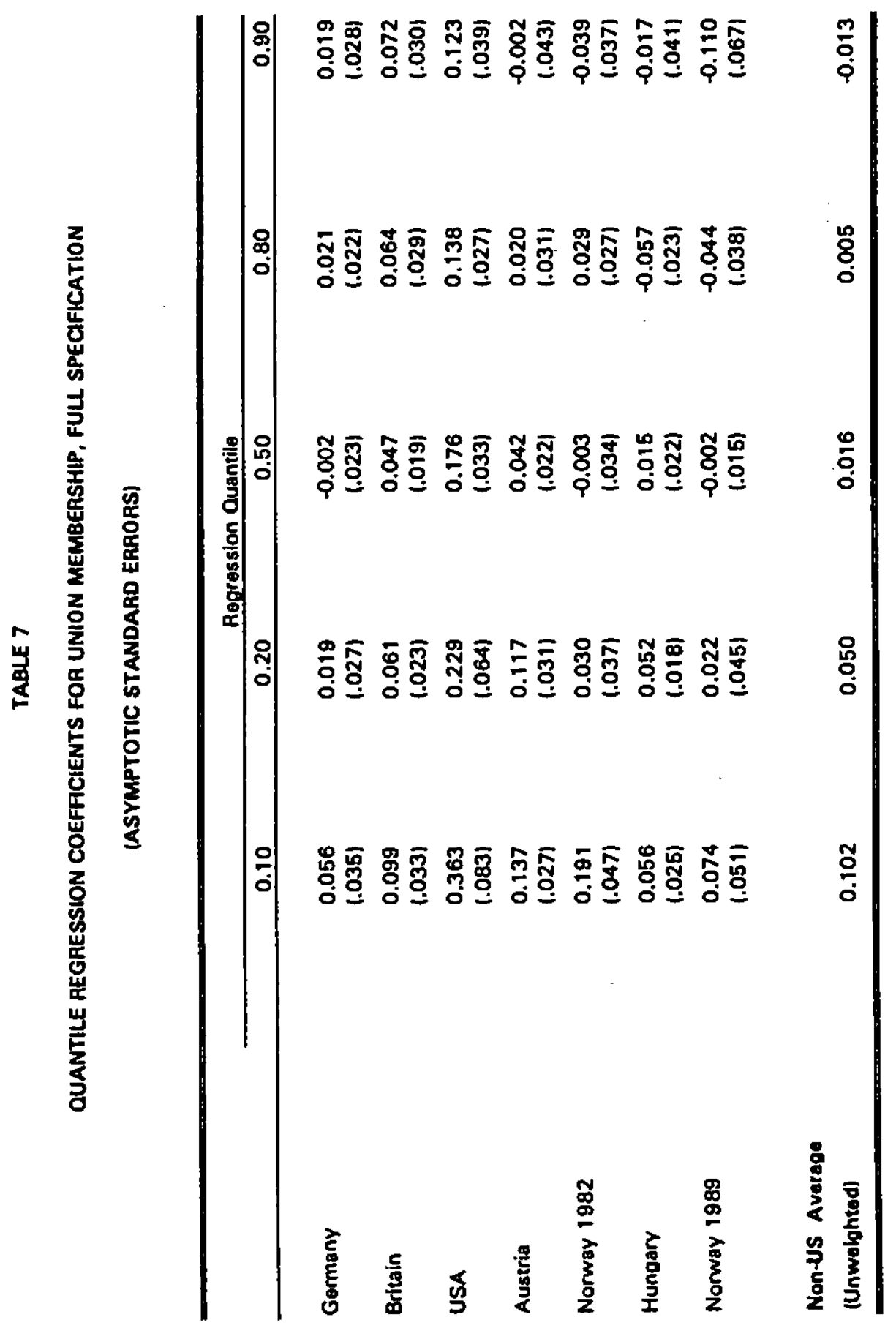




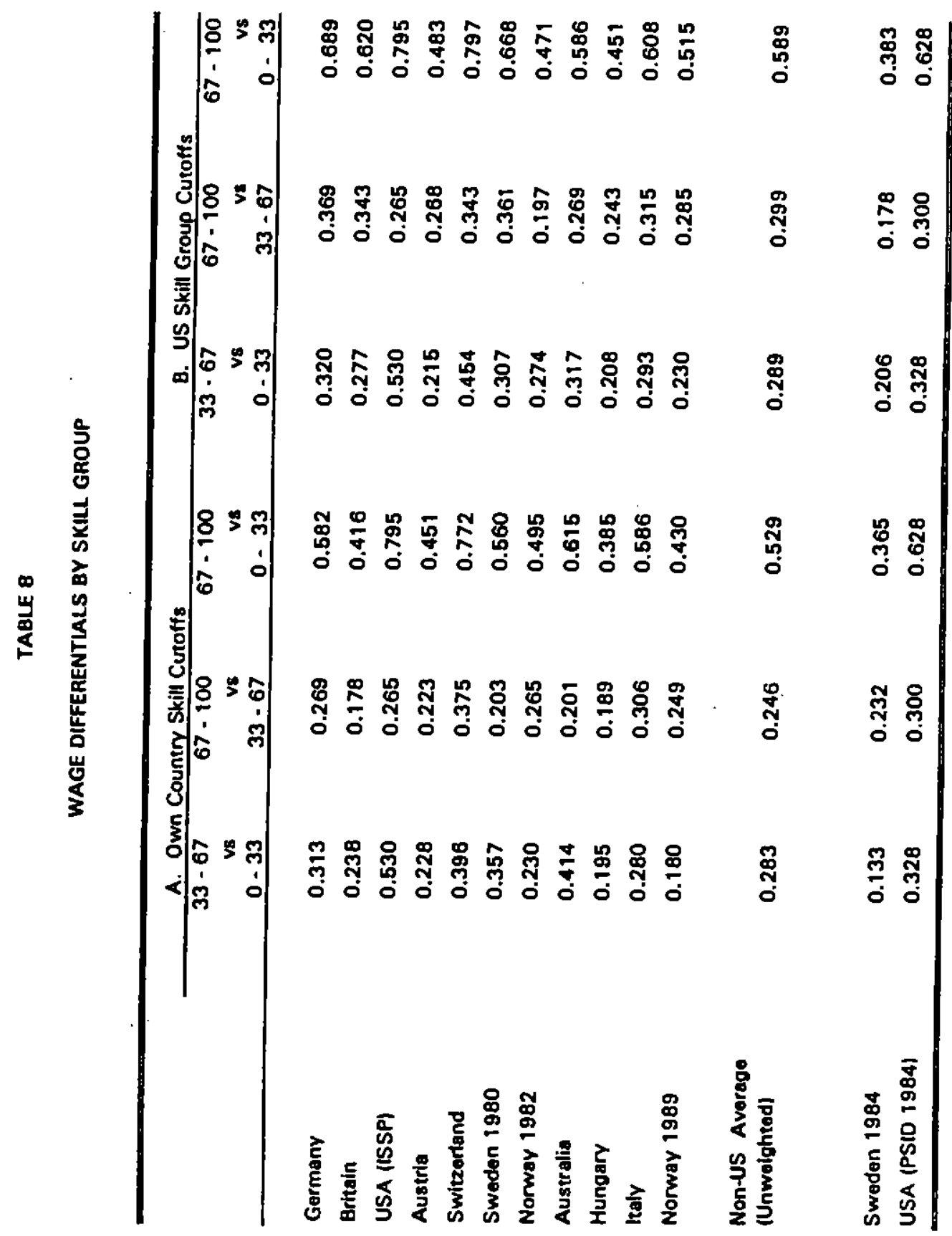

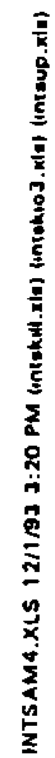




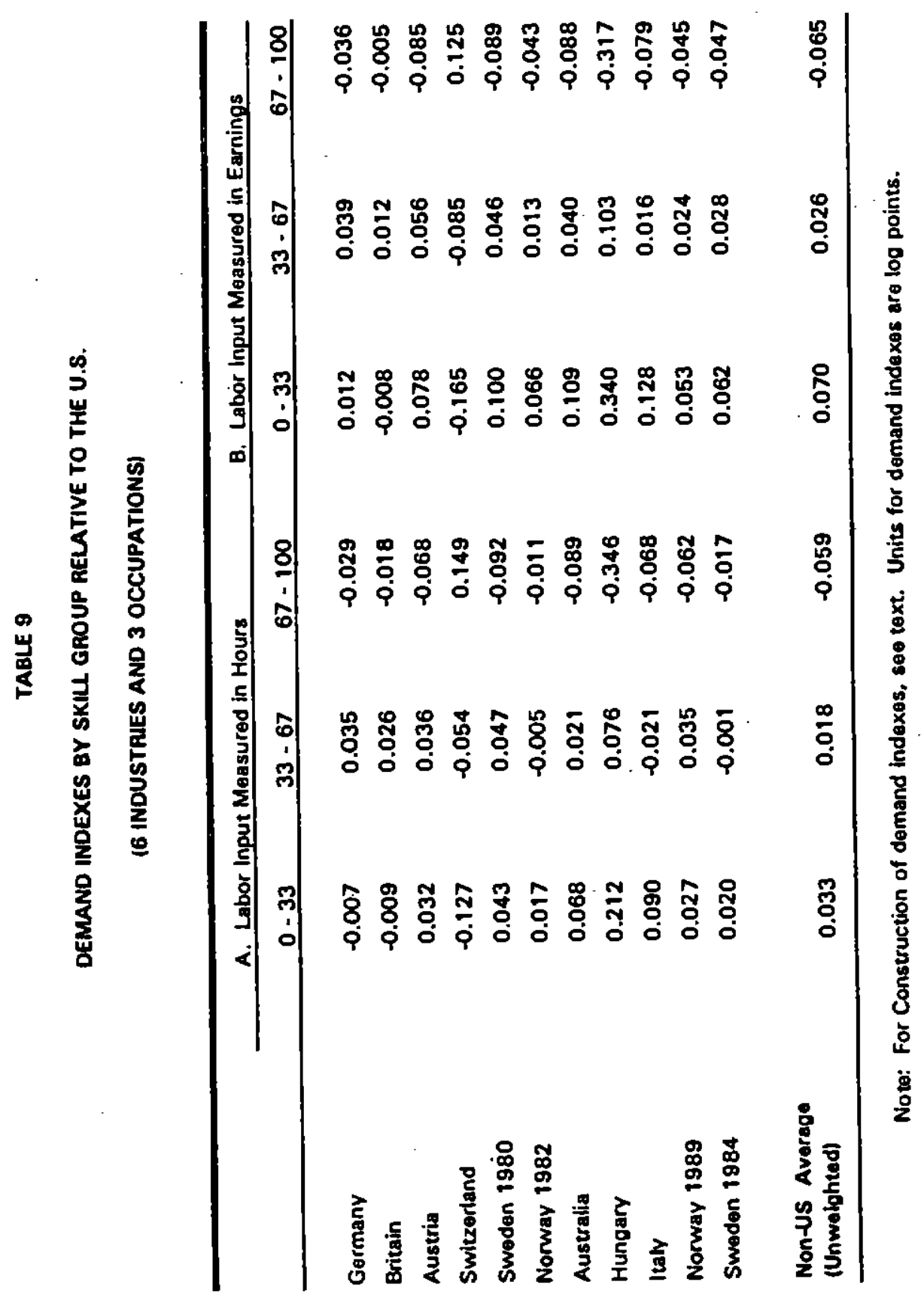




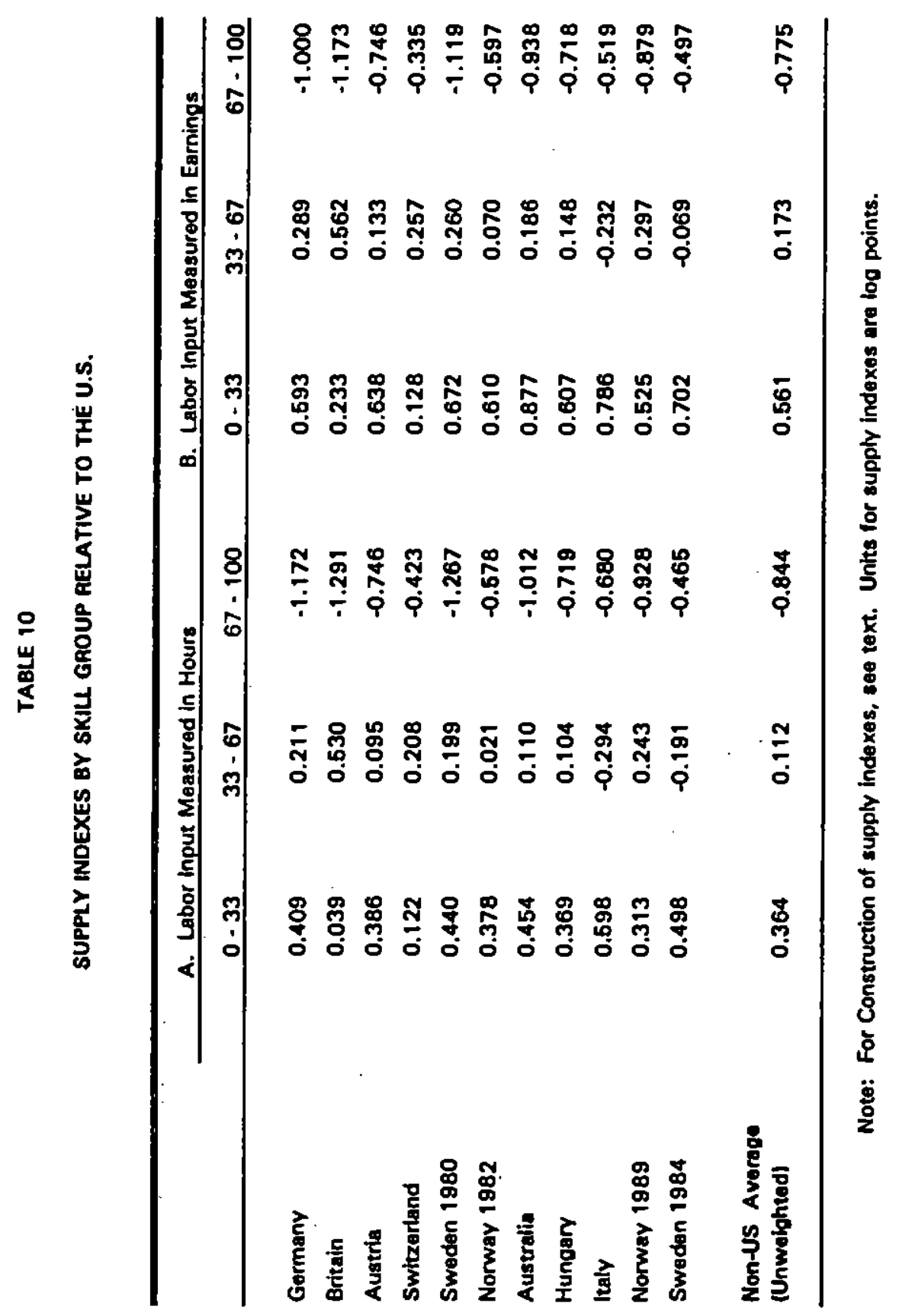




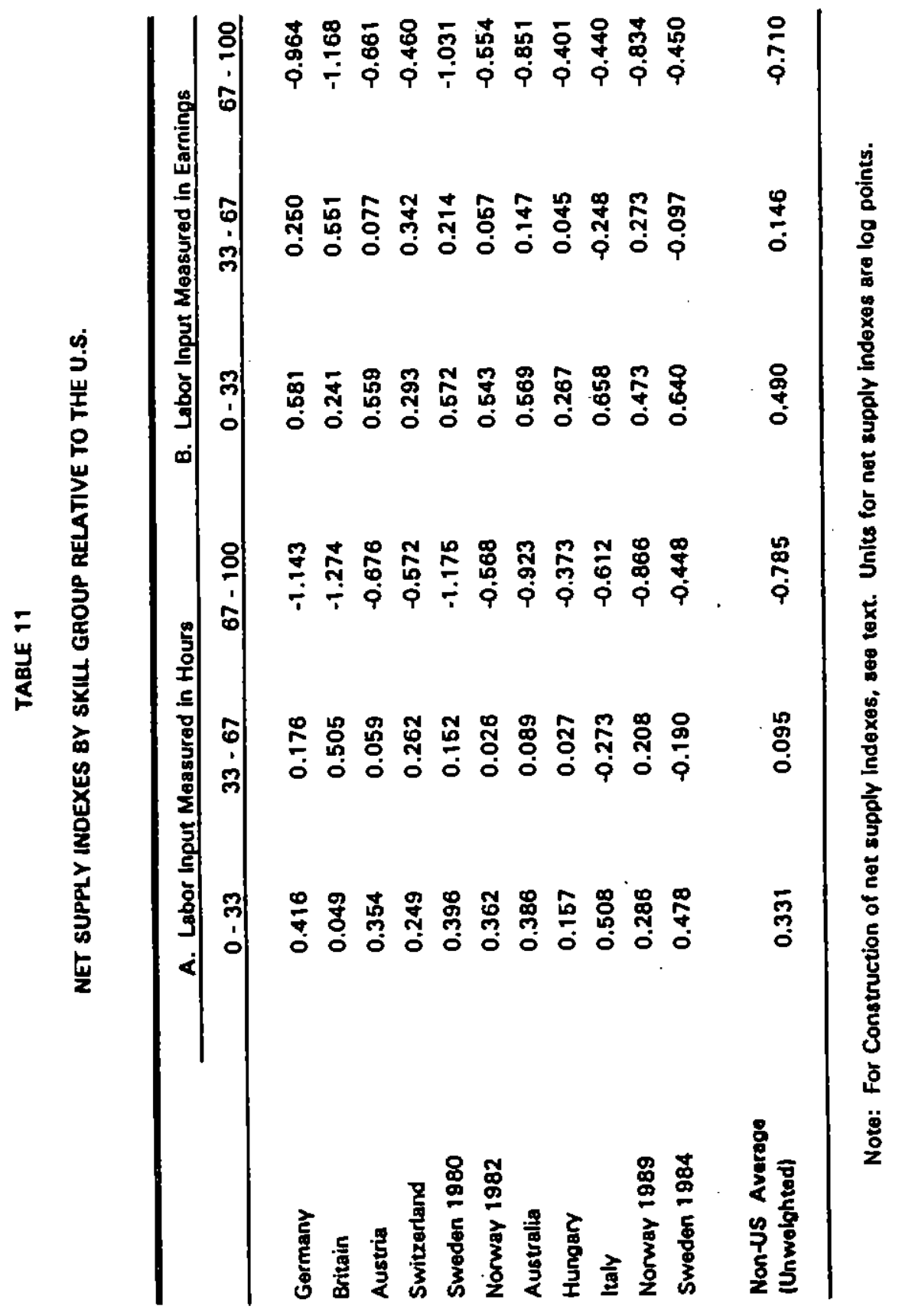


TABLE 12

EFFECTS OF CENTRALZATIDN DF WAGE-SETTING AND FEMALE LABDR SUPPLY ON MALE WAGE INEQUALTY

\begin{tabular}{|c|c|c|c|c|}
\hline \multirow[b]{2}{*}{ Dependent Variable } & \multicolumn{4}{|c|}{ Regression Results for } \\
\hline & $\begin{array}{c}\text { DECENT } \\
\text { (1) }\end{array}$ & $\begin{array}{c}\text { DECENT } \\
(2) \\
\end{array}$ & $\begin{array}{l}\text { LNFEM } \\
\text { (1) }\end{array}$ & $\begin{array}{l}\text { LNFEM } \\
\text { (2) } \\
\end{array}$ \\
\hline Standard Deviation of YFULL & $\begin{array}{l}0.0133 \\
(.0051\}\end{array}$ & $\begin{array}{l}0.0148 \\
(.0054)\end{array}$ & $\begin{array}{l}0.0392 \\
(.2307)\end{array}$ & $\begin{array}{l}0.1747 \\
(.1780)\end{array}$ \\
\hline 50-10 Differential of YFUU & $\begin{array}{l}0.0269 \\
1.00991\end{array}$ & $\begin{array}{l}0.0322 \\
(.0084)\end{array}$ & $\begin{array}{l}0.3344 \\
(.4392)\end{array}$ & $\begin{array}{l}0.6295 \\
(.2768)\end{array}$ \\
\hline 90-50 Differential of YFULL & $\begin{array}{l}0.0044 \\
(.0072)\end{array}$ & $\begin{array}{l}0.0040 \\
(.0080)\end{array}$ & $\begin{array}{r}-0.0828 \\
(.2437)\end{array}$ & $\begin{array}{r}-0.0457 \\
(.2663)\end{array}$ \\
\hline $\begin{array}{l}\text { Standard Deviation of YFULL, } \\
\text { Corrected for Personal } \\
\text { Characteristics }\end{array}$ & $\begin{array}{l}0.0127 \\
(.0049)\end{array}$ & $\begin{array}{l}0.0144 \\
(.0049)\end{array}$ & $\begin{array}{r}-0.0679 \\
(.2182)\end{array}$ & $\begin{array}{l}0.2001 \\
(.1624)\end{array}$ \\
\hline $\begin{array}{l}\text { 50-10 Differential, Corrected } \\
\text { for Personal Characteristics }\end{array}$ & $\begin{array}{l}0.0155 \\
(.0072)\end{array}$ & $\begin{array}{l}0.0173 \\
(.0077)\end{array}$ & $\begin{array}{l}0.0473 \\
(.3003)\end{array}$ & $\begin{array}{l}0.2058 \\
(.2547)\end{array}$ \\
\hline $\begin{array}{l}\text { 90-50 Differential, Corrected } \\
\text { for Personal Characteristics }\end{array}$ & $\begin{array}{l}0.0095 \\
(.0056)\end{array}$ & $\begin{array}{l}0.0108 \\
(.0059)\end{array}$ & $\begin{array}{l}0.0648 \\
(.2149)\end{array}$ & $\begin{array}{l}0.1642 \\
(.1969)\end{array}$ \\
\hline Specification & $\begin{array}{c}\text { DECENT } \\
\text { only }\end{array}$ & $\begin{array}{l}\text { DECENT } \\
\text { and } \\
\text { LNFEM }\end{array}$ & $\begin{array}{l}\text { LNFEM } \\
\text { only }\end{array}$ & $\begin{array}{l}\text { DECENT } \\
\text { and } \\
\text { LNFEM }\end{array}$ \\
\hline Sample Size & 10 & 10 & 10 & 10 \\
\hline
\end{tabular}

Note: DECENT is defined in the text and is an inverse measure of wage-setting centralization; LNFEM is the log of the ahare of total work hours accounted for by women. A constant term is included in ali regressions. 
TABLE 13

EFFECTS OF CENTRALIZATION, NET SUPPLY AND FEMALE LABOR SUPPLY DN MALE SKILL GROUP WAGE DIFFERENTLALS

\begin{tabular}{|c|c|c|c|c|}
\hline \multirow[b]{2}{*}{ Explanatory Variables } & \multicolumn{4}{|c|}{ Dependent Variable } \\
\hline & $\begin{array}{r}\text { Middle vs. Low } \\
\text { OWMIDLOW }\end{array}$ & $\begin{array}{r}\text { High vs. Middle } \\
\text { OWHIMID }\end{array}$ & $\begin{array}{r}\text { Middle vs. Low } \\
\text { OWMIOLOW }\end{array}$ & $\begin{array}{r}\text { High vs. Middle } \\
\text { DWHIMIO } \\
\end{array}$ \\
\hline Decentralization & $\begin{array}{l}0.0113 \\
(.0057)\end{array}$ & $\begin{array}{l}0.0024 \\
(.0027)\end{array}$ & $\begin{array}{l}0.0122 \\
(.0048)\end{array}$ & $\begin{array}{l}0.0025 \\
(.0031)\end{array}$ \\
\hline Net Supply & $\begin{array}{l}0.0540 \\
(.0979)\end{array}$ & $\begin{array}{r}-0.0540 \\
(.0288)\end{array}$ & $\longrightarrow$ & --- \\
\hline Female Labor Supply & $\begin{array}{r}-0.0603 \\
(.1882)\end{array}$ & $\begin{array}{r}-0.0807 \\
(.0942)\end{array}$ & - & $\cdots$ \\
\hline Constant & $\begin{array}{r}-0.3024 \\
(.0582)\end{array}$ & $\begin{array}{r}-0.0447 \\
(.0345)\end{array}$ & $\begin{array}{r}-0.3076 \\
(.0453)\end{array}$ & $\begin{array}{l}0.0161 \\
(.0297)\end{array}$ \\
\hline Sample Size & 10 & 10 & 10 & 10 \\
\hline
\end{tabular}

Note: Variables are relative to the U.S. DWMIDLOW and DWHIMID are middle-tow and high-middle skill group log wage aaps; net supply is the relative net supply of the relevant pair of skill groups: female labor supply is LNFEM. 